\title{
A Partial Least-Square Mediation Analysis of the Contribution of Cross-Campus Entrepreneurship Education to Students' Entrepreneurial Intentions
}

\author{
Anca-Otilia Dodescu ${ }^{1, *(\mathbb{C})}$, Elena-Aurelia Botezat ${ }^{2}$, Alexandru Constăngioară ${ }^{2}$ and Ioana-Crina Pop-Cohuţ ${ }^{1}$ (i) \\ 1 Department of Economics and Business, Faculty of Economic Sciences, University of Oradea, \\ 1 University Street, 410087 Oradea, Romania; ipop@uoradea.ro \\ 2 Department of Management and Marketing, Faculty of Economic Sciences, University of Oradea, \\ 1 University Street, 410087 Oradea, Romania; ebotezat@uoradea.ro (E.-A.B.); \\ aconstangioara@uoradea.ro (A.C.) \\ * Correspondence: otiliaanca.dodescu@gmail.com or adodescu@uoradea.ro; Tel.: +40-752-100-800
}

check for updates

Citation: Dodescu, A.-O.; Botezat,

E.-A.; Constăngioară, A.; Pop-Cohuţ, I.-C. A Partial Least-Square Mediation Analysis of the Contribution of Cross-Campus Entrepreneurship Education to

Students' Entrepreneurial Intentions. Sustainability 2021, 13, 8697. https:// doi.org/10.3390/su13168697

Academic Editors:

Carlos Lopez-Gutierrez,

Ana Fernandez-Laviada and Andrea Pérez

Received: 5 July 2021

Accepted: 2 August 2021

Published: 4 August 2021

Publisher's Note: MDPI stays neutral with regard to jurisdictional claims in published maps and institutional affiliations.

Copyright: (C) 2021 by the authors Licensee MDPI, Basel, Switzerland. This article is an open access article distributed under the terms and conditions of the Creative Commons Attribution (CC BY) license (https:/ / creativecommons.org/licenses/by/ $4.0 /)$.

\begin{abstract}
The present paper presents findings of entrepreneurial intentions of a group of 313 undergraduate students of the University of Oradea, Romania, from different non-economic fields of study (engineering, health, social sciences, mathematics, natural sciences, humanities, and arts), including students from rural areas and other disadvantaged groups enrolled in an entrepreneurship education project financed through European Social Fund. A complex mediation chain is set in place in a net of relationships linking the benefits of entrepreneurial education to entrepreneurship self-efficacy, entrepreneurship attitudes, perceived behavioral control, and subjective norms in our estimation of entrepreneurial intentions. Using a multigroup analysis, we address the OECD inclusive entrepreneurship perspective of students 'at-risk' on the labor market and under-represented in entrepreneurship, identifying how the benefits of entrepreneurship education can be better capitalized by each category. The present paper advocates the necessity to extend entrepreneurship education outside the economics and business specializations.
\end{abstract}

Keywords: student's entrepreneurship; entrepreneurship education; entrepreneurial intentions; cross-campus; inclusive entrepreneurship; social impact

\section{Introduction}

At the beginning of the 20th century, Schumpeter defined the entrepreneur as an innovator, revolutionizing, changing existing relations and production techniques, leading the economy towards better use of capital and knowledge [1]. Schumpeter's vision of 'innovative entrepreneur' and entrepreneurship as a 'process of creative destruction' - the force that underpins economic development [1], is almost universally acknowledged as the most synthetic explanation of the role of entrepreneurs and entrepreneurship in economic thought.

Today, the entrepreneurial theory focuses not just on the economic value addition but also on the social value an organization creates. Entrepreneurship affects communities, societies, and humanity, encompassing macro-economic effects through innovation, competition, and restructuring [2]. Also, entrepreneurship has been connected to create "a special form of employability" [3], has been recognized as a career opportunity, supporting personal development, and providing means of self-fulfillment, especially with the support of higher education $[4,5]$.

The fast growth of Entrepreneurship Education (EE) in universities reflects the underlying assumption that EE fosters increased levels of entrepreneurship [6-9]. Nowadays, $\mathrm{EE}$ is related to much more than economic activities and business creation. Policymakers support EE for unlocking personal potential [10] and its contribution to developing key competencies for lifelong learning. European Union defined entrepreneurship competence as "the capacity to act upon opportunities and ideas and to transform them into 
values for others" [11] (p. 15). The most important barriers to youth business creation and self-employment are the lack of knowledge and skills for entrepreneurship and the fear of failure, which highlights the importance of building entrepreneurship competencies and confidence for youth in a multidisciplinary environment [12] and "embedding entrepreneurship teaching at all levels of education" [13] (p. 92).

Universities face high dropout rates throughout the world, a problem manifesting itself with an increasingly strong intensity from year to year. In Europe, Romania, Malta, Portugal, and Spain are ranked among the countries with the highest school dropout rate. This phenomenon is attributable mainly to deepening poverty. However, learning difficulties, social problems, or lack of motivation, guidance, or support contribute to it [14]. In Romania, university dropout is a major concern, especially for the rural youth and the Roma minority. With a negative impact on the educational level of students, dropout has become a risk for youth exclusion from the labor market. Generating a large negative impact on human capital, dropout also contributes to a lack of integration among individuals [15]. To curb the dropout rates and contribute to social inclusiveness, the University of Oradea uses cross-campus EE to increase the attractiveness of their educational offer, targeting students from social categories 'at-risk' in the labor market and under-represented in entrepreneurship.

Based on the inclusive entrepreneurship research framework developed by OECD [13], we considered EE's aim to support students' business creation and students' entry into selfemployment, looking not only to promote students' entrepreneurship but also to support students' self-employment and employability.

This study focuses on analysing the transmission mechanisms of the benefits of $\mathrm{EE}$ on the Entrepreneurial Intention (EI) of non-economics students participating in a cross-campus EE project financed through the European Social Fund, implemented at the University of Oradea. Considering recommendations from empirical work in the field we are drilling down into the minutiae of the mediation chain by which the benefits of the $\mathrm{EE}$ programs increase EI of students from non-economics specializations.

We consider that the role of EE extends beyond building entrepreneurial awareness and competencies. EE is increasing the attractiveness of the educational offer, alleviating the student dropout phenomenon, and contributing to the inclusiveness of students at risk in the labor market. Consequently, our analysis is also aiming to test if pre-defined data groups have significant differences in their group-specific parameter estimates. Focusing on a multi-group analysis allows us to identify how the benefits of EE are being transmitted more efficiently for each category of students 'at-risk' or under-represented in entrepreneurship. Equally important, a multi-group analysis allows us to identify the different barriers that might be deterring the EE-EI relationship for students at risk or under-represented in entrepreneurship.

Our estimation strategy first identifies the benefits of EE perceived by non-economics students participating in an EE program and subsequently uses them as inputs in our structural modelling of EI. Our contribution to the literature in the field consists of proposing a mediation approach to estimating the relationship between subjective norms and entrepreneurial intentions. We also contribute to the existing literature in the field by testing the conventional wisdom embedded in planned behavior modes that external variables do not affect EI directly. In this respect, we add to the existing literature in the field by considering the transmission mechanisms for entrepreneurial self-efficacy and the benefits of entrepreneurial education.

From a methodological point of view, by employing a structural modeling approach to our estimation, the calculation of indirect effects and their statistical significance is simplifies as compared to the alternative approach suggested by Zhao et al. [16]. By employing a partial least squares (PLS) approach to structural equation modelling of EI we contribute to the existing literature in the field by proposing the importance-performance matrix as a main tool for identifying the best policy strategies in the field of EI. Our study also con- 
tributes by proposing the PLS approach for its ability to swich from reflective to formative approach in building the latent constructs employed in the analysis.

\section{Context Specific of the Analysis}

The framework conditions for entrepreneurship, including the general regulatory environment for start-ups, are less favourable in Romania than in the European Union [17]. The labor market in Romania displayed various mismatches and shortages. The lowest unemployment rate since the country has begun its transition to the market economy coexisting with the lowest labor force participation rates in the European Union, high poverty and inequality, and the decline of the active population, due to emigration of skilled labor and demographic changes [17-19].

The rural-urban divide is a particular challenge for Romania's labor market [19]. In Romania, agriculture accounts for $24 \%$ of the total employment, the largest share in the European Union for this sector. This workforce largely consists of self-employed and contributing family workers, the latter category being made by young women [17], which explains the gender gap and the age distribution of entrepreneurs in Romania. With an at-risk-of-poverty rate in rural areas five times higher than in urban areas [19], the high risk of social exclusion for vulnerable groups coupled with the rural-urban divide is the most critical feature for Romania's inclusive entrepreneurship and self-employment.

Paradoxically, Romanian young people are the most confident about their entrepreneurship skills among the EU Member States (50.1\% compared with 25.6\% in Denmark-the least confident youth) [13] (p. 106). However, as HEInnovate shows, "the Romanian institutional context does not create a favorable framework to encourage entrepreneurial attitudes" [20] (p. 12). In our opinion, this result is explained by the positive social attitudes towards entrepreneurship and by public awareness raised by many European and national programs attempting to support business creation (e.g., Start-up, Start-up Plus, Diaspora Start-up).

Insofar as EE is concerned, HEInnovate Romania Report [20] shows that EE in Romania is often confined to students enrolled in programs of Economic Sciences [20] (pp. 11-12), which offer specialization in economics and business-related subjects. Analyzing the Faculties of Economic Sciences curricula, Leovaridis et al. [21] have identified a large range of entrepreneurial classes. However, the educational content fostering entrepreneurship competency is not embedded across curricula or the overall university activities.

HEInnovate Romania [20] underlines that there is a commitment at a high level to implement the entrepreneurial agenda in Romanian universities, with action being encouraged by the Ministry of Education, including the use of HEInnovative tool. They later implemented the "Entrepreneurial University Program" in 34 Universities. At the level of individual universities, the commitment to developing an entrepreneurial agenda varies, with several good practices being identified in major universities across Romania.

The starting point of the present study is an EE project financed through the European Social Fund at the University of Oradea, Romania, addressing inclusiveness and dropout prevention of students from social categories at risk in the labor market. The target group of the project is represented by 450 students from non-economics specializations, 330 of them from social categories considered at risk in the labor market (308 from rural areas, 6 with disabilities, one from Roma minority, and 13 non-traditional students with socioeconomic difficulties). In order to achieve its incentives, the project offers integrated services of EE and career counseling, offering us the opportunity to conduct our analysis.

The paper is structured as follows: Section 2 overviews the existing EE-EI literature. Section 3 considers the research hypotheses and methodology; Sections 4 and 5 present the methodology, data, and empirical estimation results. Sections 6 and 7 summarize and conclude the paper. 


\section{Literature Review}

Universities are well situated for building youth's entrepreneurial competencies. Fostering entrepreneurial awareness and incorporating entrepreneurial mindsets into students' attitudes through EE are increasingly recognized as part of a university's role [22-24].

Universities are encouraging students to consider entrepreneurship as a potential career path mainly by the provision of theoretically oriented courses which teach 'about' entrepreneurial traits, awareness, the impact of courses or impact of different cultures on entrepreneurship [6] and provide training in conventional management-related subjects such as business plans, marketing, financial management or small business management [8].

Of all outcomes of EE, EI is considered the best single predictor of entrepreneurship behavior [6,25-27]. This assumption is embedded in a large body of research in the field focusing on EI (51\%, according to Nabi et al. [9]). In most empirical research, EI is simply defined as "the intention to start a new business" [26] at some point in the future that might be imminent, indeterminate, although it may never be reached [28]. Another popular approach considers EI as the intention to become self-employed [29].

In our analysis, we draw on Souitaris et al. [30] to define the benefits for students of EE: learning, program-derived entrepreneurial inspiration, and incubation resources. Learning covers the entrepreneurship knowledge acquired by students during the EE program. Inspiration is seen as a change of heart and mind, or a change of emotion and motivation provoked by the EE program and oriented towards considering becoming an entrepreneur [30]. Finally, the incubator resources cover advice from faculty members and from a pool of entrepreneurial-minded classmates from building a team. We also emphasize that the benefits of EE are being built in an entrepreneurship program, which includes a portfolio of activities complementing the traditional teaching.

\subsection{Empirical Approaches to Estimations of Entrepreneurial Intentions}

A large body of empirical estimations of EI has been guided by two models: Shapero and Sokol's Model of Entrepreneurial Event [31] and Azjen's Theory of Planned Behavior [32].

Shapero and Sokol's Model of Entrepreneurial Event (SEE) considers that EI is predicting actual entrepreneurship behavior. As factors that control an individual's EI, SEE is focusing on perceived desirability, feasibility, and propensity to act. In the context of EI, perceived desirability refers to how attracting is the entrepreneurship endeavor for a person. Perceived feasibility quantifies the degree to which one feels capable of starting a business [33], and perceived propensity to act reflects the volitional aspects of intention [29].

Starting from SEE and due to the integration of major social psychology theories: the social cognitive theory (SCT) [34,35] and the theory of planned behavior (TPB) $[32,36]$, empirical analyses of the EI are increasingly common, most of them have developed their own models. Integrated and mixed versions of SEE, SCT, and TPB have served as major theoretical grounds for these models.

Although it was not developed specifically for EI, it has become popular in modeling EI after its empirical validation [37]. In the context of EI, TPB states that intentions are determined by attitudes toward entrepreneurship, subjective norms (or perceived social pressure to engage or not in entrepreneurship), and perceived behavioral control.

Obviously, TPB and SEE models have overlapping mechanisms of EI formation. In an effort to integrate both theories, Krueger et al. [33] argue that subjective norms overlap with desirability and feasibility and that feasibility overlaps with perceived behavioral control. In their turn, Iakovleva and Kolvereid [29] show that perceived desirability and feasibility, integrated into one construct, mediate the influence of attitude, subjective norms, and perceived behavioral control on EI.

In sum, the TPB models have been developed to improve the estimation of intentions and, when applied to estimating the EI, they successfully explain from $40 \%$ to $60 \%$ in the variation of the EI construct, which represent a significant improvement over the initial estimations of EI which were only controlling for personal traits [29]. 
Nevertheless, improvements to the general framework of the TBP and SEE model have been proposed in EI empirical research. Efforts have been made in search of an individual characteristic specific to entrepreneurship. Consequently, the Entrepreneurial Self Efficacy (ESE) concept was introduced for the study of EI [37,38]. ESE refers to the belief in an individual's ability to succeed in entrepreneurial endeavors [39]. The same research points out that ESE is a task-specific construct, addressing the lack of specificity problem, specific to previous research which controls for personality traits in EI estimations. Moreover, empirical research in the field documents the statistically significant relationship between ESE and EI, with studies even considering ESE as closest to actual entrepreneurship behavior [38]. In this respective, ESE acts upon the EI and entrepreneurial emotions. From here, the benefits of ESE lead to actual entrepreneurial behavior, venture creation, and entrepreneurial performance [40].

\subsection{Transmission Mechanisms of the Benefits of Entrepreneurship Education to Entrepreneurial Intentions}

We can draw on Human Capital Theory (HCT) to understand the mechanism that enables EE to enhance entrepreneurship. Building on the THC, many studies [41-43] have argued that human capital attributes are the main determinants of entrepreneurial success. Of course, human capital encompasses not only knowledge and skills related to formal or non-formal EE but also aspects related to previous work experience and role models [44-49].

Also, the socio-cognitive models have been a suitable approach to analyze the mechanism of the benefits of EE to EI. ESE is essential in the context of measuring the EI as an output of EE, providing an important theoretical perspective linking the two concepts. According to Bandura's SCT $[34,35]$, there are four processes influencing self-efficacy development: mastery experiences, role modeling and vicarious experience, social persuasion, and judgments of one's own physiological states. Zhao et al. [25] analyze the specific configuration of ESE as an antecedent of EI. They argue that the pedagogical practices specific to entrepreneurship courses impact, without exception, all these processes: "enactive mastery (simulated business exercises, best business case competition, the provision of venture capital to entrepreneurship students), role modeling and vicarious experience (successful local entrepreneurs invited to lecture, case studies of prestigious entrepreneurs presented, project work with an entrepreneur, etc.), social persuasion (students' projects evaluation, students' career mentoring, etc.), judgments of one's physiological states (helping students to develop their psychological coping strategies through examples of the lifestyles and working styles of successful entrepreneurs, etc.)."

As Figure 1 shows, firm characteristics and cultural and institutional environment also contribute to the development of the ESE construct.

HCT and SCT provide thereby the two theoretical perspective linking EE to EI and further on to entrepreneurship behavior. Accordingly, the TPB models have been used to analyses the influence of EE on students' EI [27].

\subsection{Cross Campus Entrepreneurship Education Approach}

Numerous empirical studies that explore the efficiency of entrepreneurial university supply worldwide, including Romania [21,50-54], show that the EI is significantly positively related to the entrepreneurial orientation of the university [46]. It is widely recognized that business orientation is a significant determinant of students' attitude toward entrepreneurship $[21,55,56]$, and entrepreneurial education should be extended outside the business school [57], especially at engineering programs [50,58]. 


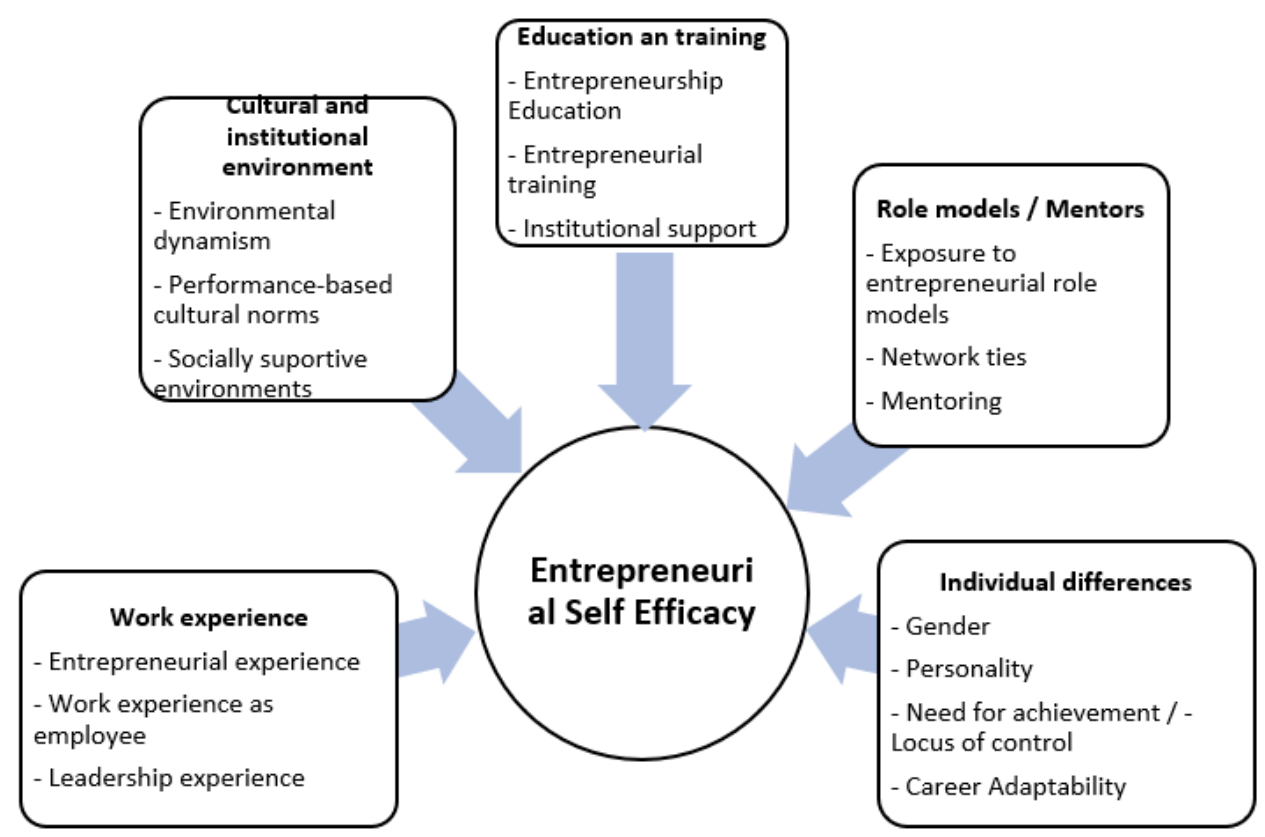

Figure 1. The antecedents of Entrepreneurial Self-Efficacy. Source: Adapted from Newman et al., 2019 [40].

As a response to criticism about its coverage area and effectiveness, EE has broadened its objectives and means worldwide, allowing students from all levels and fields of study to develop their entrepreneurial skills in parallel with life skills and career coaching.

EE expansion beyond economics faculties and business schools has given entrepreneurship education increased flexibility and greater applications [59]. Cross-campus EE [59-61] or radiant university-wide model in EE $[62,63]$ is focusing on the specific context of nonEconomics students with entrepreneurship courses outside the Faculty of Economics. A cross-campus approach to EE is considered "extremely appealing to students" [63] because it allows the formation of entrepreneurial competencies within the faculty and customized on the specialization followed, but it has two major disadvantages: high cost and administrative difficulties.

If these obstacles are overcome, the cross-campus EE approach opens the perspective of a broad rethinking of entrepreneurship education in universities outside the Economics faculties and Business schools $[64,65]$. The advantages of this model of entrepreneurship education are much greater from the perspective of customizing entrepreneurial education in the students' field of study. This model simulates the students' EI in their field of study and allows EE to connect with self-employment and employability.

As Decker-Lange [66] recently showed, "employability and entrepreneurship skills overlap", this is the reason why cross-campus EE is helpful in nurturing not only entrepreneurship and self-employment but also employability.

\subsection{Entrepreneurship Education and Its Contribution to Inclusive Entrepreneurship}

The origin and practice of inclusive entrepreneurship are linked to a project having the same name led by Syracuse University in partnership with the Burton Blatt Institute. The program has fostered a better understanding of the entrepreneurial ecosystem and the skills needed for successful entrepreneurs, providing participants with opportunities to channel their creativity, develop the skills and the drives for entrepreneurial pursuits [67].

The concept of inclusive entrepreneurship was quickly adopted by policymakers throughout the world. OECD approaches inclusive entrepreneurship from a mixed perspective: business creation for disadvantaged or under-represented groups in entrepreneurship and self-employment for people at risk [68] (pp. 18-19). Inclusive entrepreneurship has also been addressed within the European Union's strategy for more and better jobs 
through the Community for Practice on Inclusive Entrepreneurship (COPIE) project led to developing specific tools for under-represented groups in entrepreneurship.

In recent years, youth have been a typical target group for inclusive entrepreneurship policy in European Union and OECD countries. European Commission has included entrepreneurship competence as a key competence that all individuals need for personal fulfillment and social inclusion [11]. Consequently, EE also serves the objective of inclusiveness through its contribution to increasing the human capital of students. Among the best practices in Romanian higher education, we mention that already Romanian universities are using EE as a tool for increasing the attractiveness of its educational content, contributing to alleviating the school dropout phenomenon, which, in Romania, is considered a social risk [69-72].

Within the framework of inclusive entrepreneurship, extensive research is focusing on gender differences in entrepreneurship. Research has documented the existence of a gender gap in entrepreneurship, with women being less successful entrepreneurs than men [73-75]. Some studies directly associate entrepreneurial intention with masculine traits [76-78].

\section{Research Framework and Hypothesis Development}

According to Zhao et al. [25], Pillis and Reardon [26], and Ozaralli and Rivenburgh [27], we start by considering EI as the best predictor of the decision to become an entrepreneur.

Predicting EI by controling only for an individual or contextual factors results in small explanatory power and even smaller predictive validity $[33,79]$. TPB and SEE provide a robust theoretical framework for modelling EI $[33,80,81]$. Our analysis follows the general framework of the TPB, identifying entrepreneurial attitudes, subjective norms, and perceived behavioral control as antecedents of EI. Our previous empirical research among Economics students based on TPB confirms a positive relationship between students antecedents (i.e., attitude toward behavior, subjective norms, and perceived behavioral control) and EI more powerful than the one between students' experiences (i.e., exposure to entrepreneurial models, work experience, and intuition of trigger-events) and EI [82].

The present research's focus is to study the impact of EE and knowledge on noneconomic students' EI. Most of the empirical research in the field has found that EE has a positive impact on students' EI [6,24,30,81,83-88], including for science and engineering students $[24,30]$. Also, many studies report that $\mathrm{EE}$ has a statistically significant impact on entrepreneurial skills [89-91]. There are also studies that report insignificant effects [24] or even negative effects arguing that EE better informs students also on the risks involved in entrepreneurship and thereby are discouraging EI [7]. Within the same line of reasoning, there are also studies that claim that EE rather prepares students for work, increasing risk aversion and inhibiting entrepreneurial intention [86,92-95].

In our opinion, the mixed empirical support for the contribution of EE on EI is partially attributable to the methodological approach to the estimation. First, we acknowledge that a plethora of studies provide empirical support for the contribution of EE to ESE [25,40,90]. It is also generally acknowledged that ESE is a key determinant of EI [40]. Further on, we draw on findings in EI estimations that show that external variables do not affect intentions or the behavior itself directly. Their impact is mediated by the antecedents of intentions $[48,96]$.

Further on, we quantify in our research the benefits of EE proposed by Souitaris et al. [30]: entrepreneurship knowledge (EK), program-derived entrepreneurial inspiration, and incubation resources. We group the last two categories into a category named Inspiration and Resources (IR).

Building on all these findings, Souitaris et al. [30] provide supporting evidence that the relationship between the benefits of EE and EI is mediated by EA and PBC. Additionally, Shahab et al. [97] documents that the relationship between the EE and EI is mediated not only by the EA and PBC but also by ESE. Based on Souitaris et al. [30] and Shahab et al. [97], we formulate our research hypothesis $\mathrm{H} 1$ : 
H1 : The relationship between the benefits of EE and EI is mediated by ESE, EA, and PBC.

Peng [98] and Shahab et al. [97], bring supporting evidence that EA and PBC mediate the relationship between ESE and EI. Consequently, we formulate H2:

$\mathbf{H 2}$ : The relationship between ESE and EI is mediated by EA and PBC.

Looking deeper at the antecedent of EI, there are various controversies in the literature regarding subjective norms' ability to predict EI $[80,99,100]$ shows that, out of all the relationships, $\mathrm{SN}$ to EI received the least attention in empirical research in the field, with only $86 \%$ of empirical studies supporting it. There are empirical estimations that simply have failed to find supporting evidence for the contribution of SN to EI [33,89,101,102]. On the contrary, other estimations consider SN and EA even more important than PBC in EI estimations $[48,103,104]$. Instead of focusing on a direct relationship between SN and EI, Tsai et al. [105] documents that the impact of EA and PBC on EI depends on SN, although they have chosen a moderation model instead of a mediating one. In their turn, Krueger et al. [106], argued that SN overlaps with the notion of desirability and feasibility and that feasibility overlaps with PBC. Liñán and Fayolle [81], in their systematic review of EI literature consider that further research is needed to fully understand the transmission mechanisms embedded in EI models. Our work furthers the research in the field, and, given the mixed empirical results in the field and the different approaches to specifying the model, we consider that the recommendation of Liñán and Fayolle [81] is particularly relevant for determining the relationship between SN and EI. Consequently, based on Tsai et al. [105], Krueger et al. [106] we formulate H3.

H3 : EA and PBC mediate the relationship between SN and students' EI.

Current literature provides support for the positive relationship between working experience and EI [48,49,89,107,108]. Furthermore, Fatoki [109] showed that students with previous work experience (PWE) have a higher level of EI compared to those without. Based on all these findings, we formulate $\mathrm{H} 4$ and $\mathrm{H} 5$.

H4 : PBC mediates the relationship between PWE and students' EI.

H5 : PBC mediates the relationship between previous entrepreneurial exposure (PEE) and students' EI.

We also have investigated the barrier that may be deterring the building of students' ESE and the propagation of its influence on their EI for different groups of students at risk in the labor market or underrepresented in entrepreneurship. In this respect, we employ a multigroup analysis for all the relevant categories of students. This allows us to formulate H6 and H7.

H6: The transmission mechanism of the benefits of EE perceived by students to their EI is different for men and women.

H7 : The transmission mechanism of the benefits of EE perceived by students to their EI is different for students from the urban areas than for those from rural areas.

Our research framework is summarized in Figure 2.

Figure 2 summarizes the proposed research methodology. We have added ESE to the traditional antecedents of EI. EE is having two benefits, Entrepreneurial Knowledge (EK) and Inspiration and Resources (IR). Their effect is mediated by ESE, EA, and PBC. In addition, the relationships between previous working experience (PWE) and previous entrepreneurship exposure (PEE) to EI are mediated by PBC. 


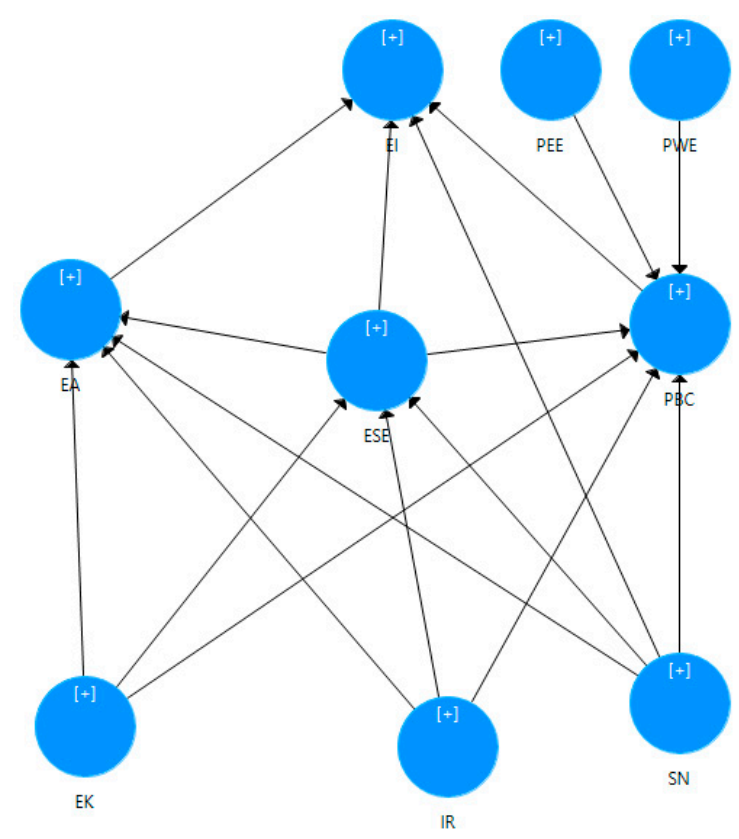

Figure 2. Research framework.

\section{Methodology and Data}

\subsection{Data}

The proposed empirical research uses a Romanian dataset concerning the determinants of EI of non-Economics students enrolled in an EE program at the University of Oradea, a university situated in the western part of Romania. The questionnaire was attended at the end of the first year of a cross-campus EE program (out of two years). The sample included students from fourteen faculties, mostly from engineering $(21.09 \%)$, socio-human sciences $(20.12 \%)$, medicine and pharmacy $(19.49 \%)$, and environmental sciences $(14.38 \%)$. The data collection was carried out during June-July 2020 using a questionnaire. From the total of 481 respondents in the study, 313 have completed the questionnaire in full. Our response rate is $65.07 \%$, similar to that reported by existing studies in the field [54]. The sample size is also similar to that employed by research in the field [52-54]. To develop the questionnaire and its themes, we followed Lorz's prior relevant work [110], cross-referenced with Romanian context data.

The participants in this study were informed from the beginning about the purpose of the research, its expected duration, and procedures. They had the right to decline participation and even withdraw from the research once it had started. Table 1 displays the frequency distribution of our respondents.

\subsection{Measures of Constructs}

The latent construct used in this research for measuring EI and its traditional antecedents are based on the Entrepreneurial Intention Questionnaire (EIQ) developed by Liñán and Chen [100] and subsequently improved by Liñán et al. [87] and Lorz [110]. The EI scale contains six items measuring students' self-acknowledged conviction to carry out entrepreneurial activities. Participants rated their conviction on a scale ranging from 1 (strongly disagree) to 5 (strongly agree). Sample items include: "I am seriously considering to open my own firm" or "I don't have any doubt about ever starting my own business". 
Table 1. Frequencies distribution.

\begin{tabular}{|c|c|c|}
\hline Respondents' Characteristics & Frequency & Percent \\
\hline \multicolumn{3}{|l|}{ Studies } \\
\hline Informatics and Science & 17 & $5.43 \%$ \\
\hline Engineering & 66 & $21.09 \%$ \\
\hline Environmental Studies & 45 & $14.38 \%$ \\
\hline Constructions & 7 & $2.24 \%$ \\
\hline Medicine and Pharmacy & 61 & $19.49 \%$ \\
\hline Socio-Human Sciencies & 63 & $20.12 \%$ \\
\hline Law & 12 & $3.83 \%$ \\
\hline Geography, Tourism, Sport & 22 & $7.03 \%$ \\
\hline Filology & 4 & $1.28 \%$ \\
\hline History and International Relations & 16 & $5.11 \%$ \\
\hline \multicolumn{3}{|l|}{ Age Category } \\
\hline $18-21$ & 153 & $49 \%$ \\
\hline $22-25$ & 106 & $34 \%$ \\
\hline 2225 & 54 & $17 \%$ \\
\hline \multicolumn{3}{|l|}{ Gender } \\
\hline Male & 100 & $32 \%$ \\
\hline Female & 213 & $68 \%$ \\
\hline \multicolumn{3}{|l|}{ Previous entrepreneurship exposure } \\
\hline $\begin{array}{llllllllllllll}1 & \text { Yes } & & & \end{array}$ & 58 & $19 \%$ \\
\hline No & 255 & $81 \%$ \\
\hline \multicolumn{3}{|l|}{ Previous work experience } \\
\hline Yes & 242 & $77 \%$ \\
\hline No & 71 & $23 \%$ \\
\hline \multicolumn{3}{|l|}{ Residence } \\
\hline Urban & 108 & $35 \%$ \\
\hline Rural & 205 & $65 \%$ \\
\hline \multicolumn{3}{|l|}{$\begin{array}{c}\text { Social category 'at risk' in the labor } \\
\text { market }\end{array}$} \\
\hline Yes & 22 & $7 \%$ \\
\hline No & 291 & $93 \%$ \\
\hline
\end{tabular}

A total of fourteen items was employed to measure the traditional antecedents of EI, five items for Entrepreneurial Attitudes (EA), six for Perceived Behavioral Control (PBC), and three for Subjective Norms (SN). Examples of EA items are: "A career as an entrepreneur is very attractive to me" and "Amongst various options and I would rather be anything but an entrepreneur". The PBC construct was measured based on Kolvereid and Iakovleva [29] with a focus on perceived controllability of behavior. Sample items include "If I tried to enter one a new business, I would have a high practicability of being successful" or "I believe it would be facile for me to develop a business idea". The items corresponding to $\mathrm{SN}$ were related to the approval of family, closest friends, and colleagues. The items used to measure the $\mathrm{EA}, \mathrm{PBC}$, and $\mathrm{SN}$ constructs required the students to answer using a five-points Likert-type scale, with possible answers ranging from "strongly disagree" to "strongly agree". In addition, for SN, in order to measure the motivation to comply family/closest friends and colleagues, respondents were asked on a five-point Likert-type scale ranging from 1 (not at all) to 5 (very much). The belief items were multiplied with motivation to comply with obtaining the overall score for SN.

The five items used for the operationalization of the Entrepreneurship Knowledge (EK) variable are based on the scale developed by Souitaris et al. [30]. Respondents were asked on five items Likert-type scale to evaluate their knowledge regarding:

- Sources of business ideas;

- Opportunity recognition;

- Business environment;

- Business authorization;

- Clients and their behavior. 
For measuring entrepreneurial inspiration, we adopted the "trigger event" approach suggested by Souitaris et al. [30]. Students were asked if a particular event or input during the program has inspired them to consider becoming an entrepreneur. Among the alternatives presented to them were professors, classmates, or external experts invites to a business plan competition. Then, they were asked: "To what extent did such an event inspired you to become an entrepreneur?". Once again, a five items scale was used to evaluate the measure of degree. If a student identified a trigger event, we have obtained the inspiration by weighting the measure of degree by 1 . Otherwise, the measure was set to zero. The resource component of the IR construct was obtained by asking students to what extent they appreciate the advice they received during the first year of the program from faculty and colleagues. Responses were evaluated on a five-item scale (from $1=$ not at all to $5=$ very much). The three items resulted were subsequently used to construct the IR latent variable.

To measure the ESE construct, we have followed Chen et al. [39] to identify five categories of entrepreneurial tasks, grouped in marketing, innovation, management, risktaking, and financial control, with each group contains several indicators. Based on Barakat et al. [111] we have proposed one indicator variable to measure its content for each category. Students were asked to evaluate their competencies regarding:

- $\quad$ Setting and meeting marketing share and sales goals;

- Ideas for developing new products and services;

- Establishing and achieving goals and objectives;

- $\quad$ Taking calculated risks;

- Performing financial analysis.

Responses were recorded using a five-item Likert-type scale with possible answers ranging from 1 = poor to $5=$ excellent.

The present research also employs demographic variables. Previous working experience and previous entrepreneurial experience were used in our estimations. Previous working experience and previous entrepreneurial experience are dichotomous variables coded $(1=$ "yes"; $0=$ "no"). Variables measuring the residence, gender, and whether or not a student is in a social category at risk in the labor market were employed to understand existing group differences better. All these variables are also binary ones, with 1= "Male", $0=$ "Female" for gender; $1=$ "Rural environment", and $0=$ "Urban environment" for the residence of the student. Also, " 1 " is used for coding when a student is in a social category "at risk in the labor market", and " 0 " in the other case.

\subsection{Method}

As required by similar studies [53,54,100,110,112], we first have conducted a thorough review of current literature in search of adequate measurement scales, ensuring the substantive and content validity of the scales. Using our previous experience [113], a test of the questionnaire was conducted in order to assess the face validity of the assertions [114]. Three categories of people were asked to participate in this stage of the testing process: five potential respondents (University of Oradea students), three academic specialists in entrepreneurship, two academic specialists in data analysis, and five market specialists (entrepreneurship experts). Consequently, the scales used in the analysis measure all facets of the underlying theoretical concepts, and all the items are conceptually and theoretically linked to the construct.

We have seven latent variables employed in our analysis: Entrepreneurial Intentions (EI), Entrepreneurial Attitude (EA), Perceived Behavioral Control (PBC), Subjective Norms (SN), Entrepreneurial Self-Efficacy (ESE), Entrepreneurial Knowledge (EK), and Inspiration and Resources (IR). Five of them (EI, EA, PBC, SN, and EK) required a reflective approach modeling and two (ESE and IR) a formative approach to obtaining the construct. Generally, in empirical research, ESE is a second-order latent construct, with entrepreneurship task-related loadings grouped in several categories. For example, Chen et al. [39] propose five categories of entrepreneurial tasks, grouped in marketing, innovation, management, risk-taking, and 
financial control, with each group containing several indicators. The indicators for each group of entrepreneurial tasks are interchangeable, and they are consequences of the construct, which requires a reflective approach to measure the respective construct $[115,116]$. However, Barakat et al. [111] use only one item for each sub-dimension of ESE. However, using a reflective approach, in this case, might affect the integrity of the construct.

In our case, we have used one item for each dimension of ESE. Since items are not mutually interchangeable and they are rather the causes of the construct, a formative approach is recommended. Similarly, in building IR construct, we have combined two benefits of EE, namely program-derived Entrepreneurial Inspiration and Incubator resources. In this case, we have also chosen a reflective approach to measuring the IR construct.

In evaluating the measurement model for formative items, two things are relevantthe statistical significance of outer weight and VIF for assessing the multicollinearity issue. For assessing the reflective constructs, we take the usual approach and consider the indicator reliability, construct convergent reliability, internal consistency, and discriminant validity of the constructs employed in the analysis.

In the second stage, to test our research hypothesis, we have conducted a confirmatory factor analysis (CFA) using a partial least-squares structural equations approach (PLS$\mathrm{SM}$ ). Our choice for structural equation modeling (SEM) was motivated by its advantages over more conventional methods such as principal component analysis [117]. SEM is more efficient in evaluating the model fit [118]. For all its advantages, SEM is best suited for analyzing the complex research framework proposed in this paper $[119,120]$. Finally, we have chosen a partial least square instead of a variance approach to SEM estimation because of its ability to grapple with small sample sizes [121], which becomes relevant in the context of employing multigroup analysis. SmartPLS uses bootstrapping for assessing the statistical significance of different results such as path coefficients, Cronbach's alphas, and even R-squares. For the bootstrapping analysis, we have set the number of samples employed to 5000, more than the 1000 samples recommended by Hair et al. [121].

\section{Results}

\subsection{Measurement Model Assessment}

In the case of reflective indicators, the results of the exploratory model show that all factor loadings are above the 0.5 thresholds required for the indicator reliability condition [122] as shown in the Table 2. In addition, all outer loadings are highly statistically significant $(p<0.001)$. All items used to measure our constructs are a good measurement of the respective construct. The Cronbach's alpha and rho a are both above the 0.7 thresholds in all cases [123]. All values for composite reliability (CR) are greater than the acceptable level of 0.7 suggested by Gefen et al. [124], indicating internal consistency. In terms of the convergent reliability, all values of average variance extracted (AVE) are greater than the threshold level of 0.5 suggested by Bagozzi and Yi [125], indicating convergent reliability. 
Table 2. Measurement model. Reflective constructs.

\begin{tabular}{|c|c|c|c|c|c|c|}
\hline & Item & Loadings & $\begin{array}{c}\text { Cronbach's } \\
\text { Alpha }\end{array}$ & rho_A & $\begin{array}{c}\text { Composite } \\
\text { Reliability (CR) }\end{array}$ & $\begin{array}{l}\text { Average Variance } \\
\text { Extracted (AVE) }\end{array}$ \\
\hline EI & $\begin{array}{c}\text { EI1 } \\
\text { EI2 } \\
\text { EI3 } \\
\text { EI4 } \\
\text { EI5 } \\
\text { EI6 } \\
\text { EA1 } \\
\text { EA2 }\end{array}$ & $\begin{array}{l}0.771^{* * *} \\
0.836^{* * *} \\
0.855^{* * *} \\
0.843^{* * *} \\
0.733^{* * *} \\
0.714^{* * *} \\
0.652^{* * *} \\
0.845^{* * *}\end{array}$ & 0.898 & 0.904 & 0.920 & 0.623 \\
\hline EA & $\begin{array}{l}\text { EA3 } \\
\text { EA4 } \\
\text { EA5 } \\
\text { EK1 } \\
\text { EK2 } \\
\text { EK3 }\end{array}$ & $\begin{array}{l}0.803^{* * *} \\
0.868^{* * *} \\
0.845^{* * *} \\
0.826^{* * *} \\
0.778^{* * *} \\
0.837^{* * *}\end{array}$ & 0.863 & 0.879 & 0.902 & 0.651 \\
\hline EK & $\begin{array}{c}\text { EK4 } \\
\text { EK5 } \\
\text { PBC1 } \\
\text { PBC2 }\end{array}$ & $\begin{array}{l}0.827^{* * *} \\
0.850^{* * *} \\
0.705^{* * *} \\
0.726^{* * *}\end{array}$ & 0.882 & 0.884 & 0.914 & 0.679 \\
\hline PBC & $\begin{array}{l}\text { PBC3 } \\
\text { PBC4 } \\
\text { PBC5 } \\
\text { PBC6 }\end{array}$ & $\begin{array}{l}0.733^{* * *} \\
0.740^{* * *} \\
0.584^{* * *} \\
0.792^{* * *}\end{array}$ & 0.810 & 0.828 & 0.862 & 0.513 \\
\hline $\mathrm{SN}$ & $\begin{array}{l}\text { SN1 } \\
\text { SN2 } \\
\text { SN3 }\end{array}$ & $\begin{array}{l}0.830^{* * *} \\
0.776^{* * *} \\
0.847^{* * *}\end{array}$ & 0.758 & 0.783 & 0.858 & 0.669 \\
\hline
\end{tabular}

Note: ${ }^{* * *} p<0.01$. For assessing the discriminant validity, we are using the Fornell-Larcker criterion.

Results in Table 3 are displaying on the principal diagonal the square root of the AVE of each construct. As Table 3 indicates, the values on the principal diagonal were significantly greater than the off-diagonal elements, meeting the criterion for validity.

Table 3. Discriminant validity.

\begin{tabular}{cccccccc}
\hline & EA & EI & EK & ESE & IR & PBC & SN \\
\hline EA & 0.807 & & & & & & \\
EI & 0.602 & 0.789 & & & & & \\
EK & 0.396 & 0.293 & 0.824 & & & & \\
ESE & 0.513 & 0.429 & 0.560 & - & & & \\
IR & 0.450 & 0.421 & 0.408 & 0.474 & - & & \\
PBC & 0.463 & 0.594 & 0.428 & 0.588 & 0.495 & 0.716 & \\
SN & 0.390 & 0.296 & 0.130 & 0.395 & 0.218 & 0.251 & 0.818 \\
\hline
\end{tabular}

In addition, cross-loading criterion [126], also indicates the discriminant validity of our constructs (Table 4 ). 
Table 4. Indicator item cross loading.

\begin{tabular}{|c|c|c|c|c|c|c|}
\hline & Item & EI & EA & PBC & SN & EK \\
\hline & EI1 & 0.771 & 0.489 & 0.364 & 0.169 & 0.194 \\
\hline \multirow[t]{7}{*}{ EI } & EI2 & 0.836 & 0.527 & 0.498 & 0.303 & 0.246 \\
\hline & EI3 & 0.855 & 0.503 & 0.522 & 0.211 & 0.259 \\
\hline & EI4 & 0.843 & 0.558 & 0.497 & 0.307 & 0.242 \\
\hline & EI5 & 0.733 & 0.395 & 0.534 & 0.159 & 0.279 \\
\hline & EI6 & 0.714 & 0.361 & 0.450 & 0.209 & 0.171 \\
\hline & EA1 & 0.382 & 0.652 & 0.298 & 0.214 & 0.250 \\
\hline & EA2 & 0.462 & 0.845 & 0.374 & 0.366 & 0.361 \\
\hline \multirow[t]{5}{*}{ EA } & EA3 & 0.469 & 0.803 & 0.350 & 0.383 & 0.248 \\
\hline & EA4 & 0.526 & 0.868 & 0.394 & 0.315 & 0.369 \\
\hline & EA5 & 0.572 & 0.845 & 0.439 & 0.282 & 0.354 \\
\hline & PBC1 & 0.370 & 0.242 & 0.705 & 0.129 & 0.252 \\
\hline & PBC2 & 0.455 & 0.335 & 0.726 & 0.106 & 0.199 \\
\hline \multirow[t]{5}{*}{ PBC } & PBC3 & 0.490 & 0.424 & 0.733 & 0.251 & 0.420 \\
\hline & PBC4 & 0.444 & 0.361 & 0.740 & 0.185 & 0.288 \\
\hline & PBC5 & 0.319 & 0.198 & 0.584 & 0.170 & 0.233 \\
\hline & PBC6 & 0.443 & 0.366 & 0.792 & 0.204 & 0.377 \\
\hline & SN1 & 0.269 & 0.337 & 0.212 & 0.830 & 0.083 \\
\hline \multirow[t]{4}{*}{$\mathrm{SN}$} & SN2 & 0.218 & 0.240 & 0.147 & 0.776 & 0.066 \\
\hline & SN3 & 0.238 & 0.359 & 0.240 & 0.847 & 0.154 \\
\hline & EK1 & 0.170 & 0.278 & 0.324 & 0.041 & 0.826 \\
\hline & EK2 & 0.260 & 0.336 & 0.356 & 0.171 & 0.778 \\
\hline \multirow[t]{3}{*}{ EK } & EK3 & 0.283 & 0.353 & 0.363 & 0.136 & 0.837 \\
\hline & EK4 & 0.228 & 0.323 & 0.351 & 0.150 & 0.827 \\
\hline & EK5 & 0.254 & 0.335 & 0.365 & 0.027 & 0.85 \\
\hline
\end{tabular}

As Table 4 shows, every single indicator loads the highest on its latent construct, both vertically and horizontally, indicating once again the discriminant validity of our constructs.

Statistical significance for the formative items is presented in Table 5.

Table 5. Outer weights of formative items.

\begin{tabular}{cccc}
\hline Path & Std. Beta & Std. Error & | t-Value I \\
\hline ESE1 -> ESE & $0.191^{* *}$ & 0.084 & 2.199 \\
ESE2 -> ESE & $0.374^{* * *}$ & 0.088 & 4.377 \\
ESE3 -> ESE & $0.310^{* * *}$ & 0.076 & 4.013 \\
ESE4 -> ESE & $0.170^{*}$ & 0.091 & 1.930 \\
IR1 -> IR & $0.308^{* *}$ & 0.124 & 2.543 \\
IR2 -> IR & $0.419^{* * *}$ & 0.121 & 3.461 \\
IR3 -> IR & $0.620^{* * *}$ & 0.068 & 9.194 \\
\hline Note: $^{*} p<0.1^{* *} p<0.05^{* * *} p<0.01$.
\end{tabular}

For formative items, all weights are statistically significant (Table 5). VIF statistics are ranging from 1.023 for IS3 to 2.203, in the case of ESE1. All values are below the threshold value of 3 recommended by Chin [126], indicating that there are no multicollinearity problems.

We use SRMR (Standardized Root Mean Residuals) to assess the overall fir of our structural model. If statistics is SRMR is below 0.08 , the data fits the model [127,128]. In our case, SMRM is 0.056 , indicating a good overall fit. A second index recommended for assessing the overall fit of the model is RMS-theta. In our case, the RMS-theta is 0.116 , indicating a good fit. Our model is explaining $49 \%$ of the variation in EI, $37 \%$ for EA, $42 \%$ for PBC, and $47 \%$ for ESE. 
5.2. Results of the Structural Analysis

5.2.1. Path Estimates of the Structural Model Analysis

The path estimates of our structural models are presented in Table 6.

Table 6. Path estimates of the structural model.

\begin{tabular}{|c|c|c|c|}
\hline Path & Std. Beta & Std. Error & | t-Value | \\
\hline EA -> EI & $0.415^{* * *}$ & 0.054 & 7.649 \\
\hline $\mathrm{EK}->\mathrm{EA}$ & $0.138^{* * *}$ & 0.052 & 2.683 \\
\hline EK -> ESE & $0.428^{* * *}$ & 0.049 & 8.721 \\
\hline EK $->$ PBC & $0.094 *$ & 0.052 & 1.873 \\
\hline ESE $->$ EA & $0.236^{* * *}$ & 0.060 & 3.882 \\
\hline ESE -> EI & -0.048 & 0.058 & 0.835 \\
\hline ESE $->$ PBC & $0.410^{* * *}$ & 0.059 & 6.853 \\
\hline IR -> EA & $0.233^{* * *}$ & 0.055 & 4.201 \\
\hline IR -> ESE & $0.242^{* * *}$ & 0.052 & 4.525 \\
\hline IR -> PBC & $0.234^{* * *}$ & 0.055 & 4.258 \\
\hline PBC -> EI & $0.420^{* * *}$ & 0.055 & 7.573 \\
\hline PEE -> PBC & $0.169 * * *$ & 0.048 & 3.534 \\
\hline PWE -> PBC & 0.007 & 0.043 & 0.150 \\
\hline $\mathrm{SN}$-> EA & $0.228^{* * *}$ & 0.050 & 4.530 \\
\hline $\mathrm{SN}->\mathrm{EI}$ & 0.051 & 0.042 & 1.228 \\
\hline $\mathrm{SN} \rightarrow \mathrm{ESE}$ & $0.284^{* * *}$ & 0.046 & 6.197 \\
\hline $\mathrm{SN}->\mathrm{PBC}$ & 0.022 & 0.043 & 0.497 \\
\hline
\end{tabular}

Most importantly, Table 6 shows that the direct relationship between ESE and EI is not supported by our data $(p=0.537)$. We also see that the coefficients corresponding to path from SN to EI and from SN to PBC are statistically insignificant $(p=0.220, p=0.619)$. All other coefficients are significant, although the coefficient corresponding to path from EK to $\mathrm{PBC}$ is only marginally significant $(p=0.061)$. While previous entrepreneurial exposure is positively and statistically significant influencing $\mathrm{PBC}$, the coefficient measuring the path PWE -> PBC is not statistically significant.

\subsubsection{Total Effects}

The total effects are presented in Table 7.

Table 7. Total effects.

\begin{tabular}{|c|c|c|c|}
\hline Path & Std. Beta & Std. Error & | t-Value I \\
\hline EA -> EI & $0.415^{* * *}$ & 0.054 & 7.649 \\
\hline $\mathrm{EK}->\mathrm{EA}$ & $0.239 * * *$ & 0.049 & 4.932 \\
\hline EK -> EI & $0.192 * * *$ & 0.035 & 5.525 \\
\hline EK -> ESE & $0.428 * * *$ & 0.049 & 8.721 \\
\hline$E K->$ PBC & $0.270^{* * *}$ & 0.048 & 5.602 \\
\hline ESE -> EA & $0.236^{* * *}$ & 0.060 & 3.882 \\
\hline ESE -> EI & $0.223^{* * *}$ & 0.059 & 3.725 \\
\hline ESE -> PBC & $0.410 * * *$ & 0.059 & 6.853 \\
\hline IR -> EA & $0.290 * * *$ & 0.051 & 5.674 \\
\hline IR -> EI & $0.248^{* * *}$ & 0.035 & 7.021 \\
\hline IR -> ESE & $0.242^{* * *}$ & 0.052 & 4.525 \\
\hline IR -> PBC & $0.333^{* * *}$ & 0.054 & 6.089 \\
\hline PBC -> EI & $0.420 * * *$ & 0.055 & 7.573 \\
\hline PEE -> EI & $0.071 * * *$ & 0.023 & 3.041 \\
\hline PEE -> PBC & $0.169^{* * *}$ & 0.048 & 3.534 \\
\hline PWE -> EI & 0.003 & 0.018 & 0.147 \\
\hline PWE $->$ PBC & 0.007 & 0.043 & 0.150 \\
\hline $\mathrm{SN}->\mathrm{EA}$ & $0.296^{* * *}$ & 0.052 & 5.732 \\
\hline $\mathrm{SN}->\mathrm{EI}$ & $0.219 * * *$ & 0.041 & 5.297 \\
\hline $\mathrm{SN} \rightarrow>\mathrm{ESE}$ & $0.284^{* * *}$ & 0.046 & 6.197 \\
\hline $\mathrm{SN}->\mathrm{PBC}$ & $0.138^{* * *}$ & 0.043 & 3.159 \\
\hline
\end{tabular}


Table 7 shows that except from previous working experience, all total effects are statistically significant.

\subsubsection{Specific Indirect Effects}

Table 8 shows that a complex mediation chain between the benefits of EE and EI. The benefits of EE are not transmitted directly through ESE. Instead, we have a complex mediation chain, with ESE, EA, and PBC acting as mediators.

Table 8. Specific indirect effects.

\begin{tabular}{|c|c|c|c|}
\hline Path & Std. Beta & Std. Error & | t-Value | \\
\hline $\mathrm{SN}->\mathrm{ESE}->\mathrm{EA}->\mathrm{EI}$ & $0.028^{* * *}$ & 0.010 & 2.691 \\
\hline ESE -> EA -> EI & $0.098^{* * *}$ & 0.029 & 3.308 \\
\hline $\mathrm{EK}->\mathrm{PBC}->\mathrm{EI}$ & $0.040 *$ & 0.022 & 1.799 \\
\hline $\mathrm{EK}->\mathrm{EA}->\mathrm{EI}$ & $0.057^{* * *}$ & 0.022 & 2.616 \\
\hline EK -> ESE -> EI & -0.020 & 0.025 & 0.829 \\
\hline IR -> EA -> EI & $0.097^{* * *}$ & 0.026 & 3.717 \\
\hline PWE $->$ PBC $->$ EI & 0.003 & 0.018 & 0.147 \\
\hline SN -> ESE -> EA & $0.068^{* * *}$ & 0.022 & 3.029 \\
\hline EK $->$ ESE $->$ PBC & $0.176^{* * *}$ & 0.034 & 5.122 \\
\hline EK -> ESE -> EA & $0.101^{* * *}$ & 0.028 & 3.608 \\
\hline $\mathrm{SN}$-> EA -> EI & $0.095^{* * *}$ & 0.025 & 3.771 \\
\hline ESE -> PBC -> EI & $0.172 * * *$ & 0.035 & 4.873 \\
\hline $\begin{array}{c}\mathrm{EK}->\mathrm{ESE}->\mathrm{PBC}-> \\
\mathrm{EI}\end{array}$ & $0.074^{* * *}$ & 0.018 & 4.127 \\
\hline IR -> ESE -> PBC & $0.100 * * *$ & 0.027 & 3.502 \\
\hline $\begin{array}{c}\mathrm{IR}->\mathrm{ESE}->\mathrm{PBC}-> \\
\text { EI }\end{array}$ & $0.042^{* * *}$ & 0.013 & 2.985 \\
\hline $\mathrm{SN}->\mathrm{PBC}->\mathrm{EI}$ & 0.009 & 0.018 & 0.486 \\
\hline IR $->$ ESE $->$ EA $->$ EI & $0.024^{* * *}$ & 0.009 & 2.678 \\
\hline IR $->$ PBC -> EI & $0.098^{* * *}$ & 0.025 & 3.841 \\
\hline $\mathrm{EK}->\mathrm{ESE}->\mathrm{EA}->\mathrm{EI}$ & $0.042 * * *$ & 0.013 & 3.144 \\
\hline $\begin{array}{c}\mathrm{SN}->\mathrm{ESE}->\mathrm{PBC}-> \\
\mathrm{EI}\end{array}$ & $0.049^{* * *}$ & 0.012 & 4.085 \\
\hline IR $->$ ESE -> EI & -0.012 & 0.015 & 0.780 \\
\hline $\mathrm{SN}->\mathrm{ESE}->\mathrm{PBC}$ & $0.116^{* * *}$ & 0.024 & 4.794 \\
\hline IR -> ESE -> EA & $0.057^{* * *}$ & 0.019 & 2.950 \\
\hline PEE -> PBC -> EI & $0.071^{* * *}$ & 0.023 & 3.041 \\
\hline $\mathrm{SN}->\mathrm{ESE}->\mathrm{EI}$ & -0.014 & 0.017 & 0.825 \\
\hline
\end{tabular}

\subsubsection{Multigroup Analysis}

Table 9 presents the results of multigroup analyze of the path coefficients by genre.

As Table 9 shows, there is a positive and statistically significant difference in the path EK $->$ ESE between men and women $(p=0.000)$. The difference in the path coefficients corresponding to ESE -> EA is also statistically significant, but this time is higher for women. Once again, the difference in the path coefficients is statistically significant and higher for men insofar as the IS -> PBC relationship is concerned while women better capitalize on the transmission of IS to ESE.

As Table 10 shows, the difference in the coefficients of the path EK -> EA is statistically significant and higher for rural students. We also note that the coefficient corresponding the path EK -> EA while statistically significant for students from rural environment is not significant for students from urban environment. 
Table 9. Multigroup analysis. Path relationships by genre.

\begin{tabular}{|c|c|c|c|c|}
\hline & Std. Beta (W) & Std. Beta (M) & $\begin{array}{c}\text { Std. Beta } \\
\text { Diff (M vs. W) }\end{array}$ & $\begin{array}{c}\text { t-Value } \\
\mid \text { M vs. W | }\end{array}$ \\
\hline EA -> EI & $0.481^{* * *}$ & $0.336^{* * *}$ & -0.154 & 1.361 \\
\hline EK -> EA & $0.126^{* *}$ & 0.170 & 0.037 & 0.316 \\
\hline EK -> ESE & $0.320^{* * *}$ & $0.646^{* * *}$ & $0.352^{* * *}$ & 3.637 \\
\hline $\mathrm{EK}->\mathrm{PBC}$ & $0.115^{* *}$ & -0.031 & -0.160 & 1.406 \\
\hline ESE -> EA & $0.350 * * *$ & 0.020 & -0.322 ** & 2.478 \\
\hline ESE -> EI & -0.071 & 0.002 & 0.080 & 0.649 \\
\hline ESE -> PBC & $0.468^{* * *}$ & $0.395^{* * *}$ & -0.063 & 0.498 \\
\hline IS -> EA & $0.172 * *$ & 0.361 & 0.195 & 1.680 \\
\hline IS -> ESE & $0.331^{* * *}$ & 0.105 & $-0.246^{* *}$ & 2.307 \\
\hline IS -> PBC & $0.209^{* * *}$ & 0.431 & $0.225 *$ & 1.894 \\
\hline PBC -> EI & 0.371 & 0.477 & 0.104 & 0.897 \\
\hline $\mathrm{SN}->\mathrm{EA}$ & $0.199^{* * *}$ & $0.308^{* * *}$ & 0.111 & 1.027 \\
\hline $\mathrm{SN}->\mathrm{EI}$ & 0.019 & 0.118 & 0.099 & 1.110 \\
\hline SN -> ESE & $0.305^{* * *}$ & $0.197^{* * *}$ & -0.113 & 1.188 \\
\hline $\mathrm{SN}->\mathrm{PBC}$ & 0.007 & 0.050 & 0.047 & 0.513 \\
\hline
\end{tabular}

Note: ${ }^{*} p<0.1,{ }^{* *} p<0.05,{ }^{* * *} p<0.01$.

Table 10. Multigroup analysis. Path relationships by residence: rural (R), urban (U).

\begin{tabular}{ccccc}
\hline & Std. Beta (R) & Std. Beta (U) & $\begin{array}{c}\text { Std. Beta } \\
\text { Diff (U vs. R) }\end{array}$ & $\begin{array}{c}\text { t-value } \\
\text { | U vs. R I }\end{array}$ \\
\hline EA -> EI & $0.576^{* * *}$ & $0.389^{* * *}$ & -0.185 & 1.534 \\
EK -> EA & -0.085 & $0.235^{* * *}$ & $0.310^{* * *}$ & 2.620 \\
EK -> ESE & $0.387^{* * *}$ & $0.489^{* * *}$ & 0.103 & 0.958 \\
EK -> PBC & 0.091 & $0.048^{* * *}$ & -0.039 & 0.320 \\
ESE -> EA & $0.278^{* *}$ & $0.265^{* * *}$ & 0.005 & 0.039 \\
ESE -> EI & -0.029 & -0.084 & -0.055 & 0.416 \\
ESE -> PBC & $0.357^{* *}$ & $0.471^{* * *}$ & 0.137 & 0.966 \\
IS -> EA & $0.268^{* * *}$ & $0.182^{* * *}$ & -0.094 & 0.781 \\
IS -> ESE & $0.233^{* *}$ & $0.218^{* * *}$ & $-0.008^{*}$ & 0.075 \\
IS -> PBC & $0.36^{* *}$ & $0.209^{* * *}$ & -0.161 & 1.351 \\
PBC -> EI & $0.218^{*}$ & $0.478^{* * *}$ & $0.273^{* *}$ & 2.288 \\
SN -> EA & $0.246^{*}$ & $0.234^{* * *}$ & -0.018 & 0.169 \\
SN -> EI & 0.030 & 0.070 & 0.039 & 0.430 \\
SN -> ESE & $0.394^{* * *}$ & $0.233^{* * *}$ & -0.167 & 1.616 \\
SN -> PBC & -0.022 & 0.071 & 0.084 & 0.843 \\
\hline Note: ${ }^{*}<0.1, * * p<0.05^{* * *} p<0.01$. & & &
\end{tabular}

\subsubsection{The Importance-Performance Matrix Analysis}

We extend the results of the PLS-SEM analysis by considering an importance-performa nce map analysis (IPMA). In a graphical representation, IPMA contrasts the unstandardized total effects (importance) in the structural model and the average values of the latent variable scores on a scale from 0 to 100. Results of the IPMA are presented in Table 11.

Table 11. Importance-performance analysis.

\begin{tabular}{ccc}
\hline Construct & Performance & Importance \\
\hline EA & 73.965 & 0.787 \\
EK & 50.896 & 0.329 \\
ESE & 62.653 & 0.398 \\
IR & 48.148 & 0.342 \\
PBC & 43.741 & 0.565 \\
SN & 76.65 & 0.273 \\
\hline
\end{tabular}


Figure 3 provides a visual representation of the differences between importance and performance for the constructs contributing to our key target variable, EI.

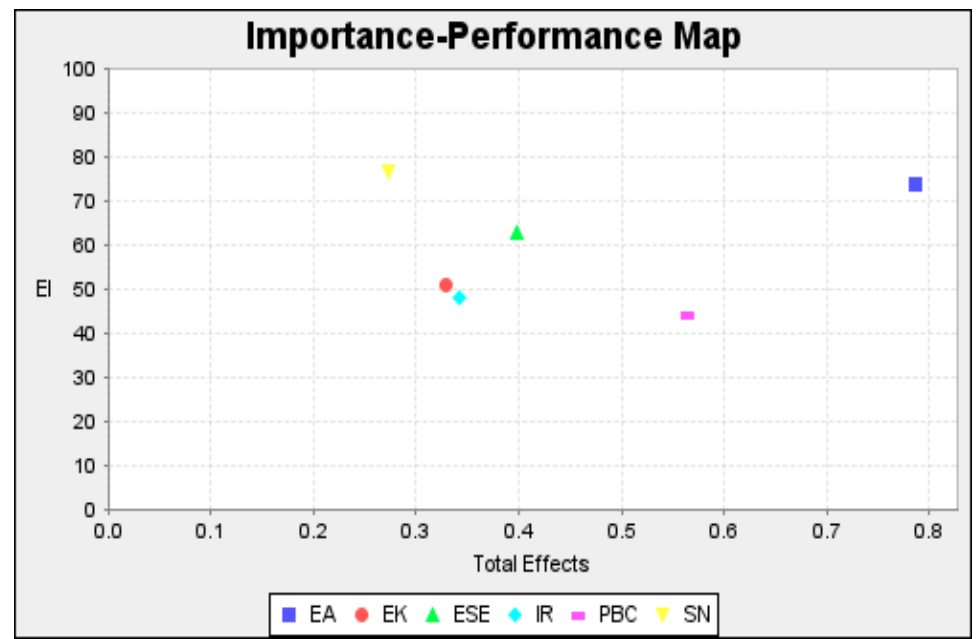

Figure 3. Importance-performance discrepancies.

We can see from Table 11 and Figure 3 that EA displays the highest combination of performance and importance. While SN display a high-performance index $(76.65 \%)$, its importance is the lowest (0.273). EK, IR, ESE, and PBC show similar performance indices. However, among them, PBC displays the highest importance index. Consequently, the greatest discrepancy between performance and importance is met for PBC. According to IPMA, PBC construct should receive highest priority for performance improvement.

\section{Discussion}

We are drawing of previous research in the field to identify three categories of entrepreneurship education benefits: entrepreneurial knowledge, entrepreneurial inspiration, and resources made available to students participating in an entrepreneurship program. Using the opportunity provided by an entrepreneurship program implemented at the University of Oradea, we have administered a survey-based empirical study that has been conducted after one year of the program's implementation.

Results of our analysis and their support for our proposed research hypothesis are summarized in Tables 12 and 13.

First, we note that we have brought supporting evidence for the assumption embedded in PBM that external effects are completely mediated by the traditional antecedents of EI. Thus, we see that ESE do no passes its influence directly to EI. The relationship between ESE and EI is mediated by EA, PBC, and SN. Moreover, since the coefficient of the path ESE-> EI is not statistically significant $(p=0.404)$, the relationship between ESE and EI is fully mediated by EA and PBC.

We contribute to existing literature in the field bringing additional evidence that $\mathrm{SN}$ do not affect EI directly. However, SN has a direct effect both on the benefits of EE and on ESE. Its impact on EI is transmitted through EA. Moreover, there is a complex mediation chain in place that link SN by EI. This chain either follows the path through ESE (SN -> ESE $\rightarrow$ PBC $->$ EI, SN $->$ ESE $->$ PBC $>$ EI) or the part through EA (SN $>$ EA $\rightarrow$ EI). Hypothesis 3 is not fully supported because the coefficient of the path SN $\rightarrow$ PBC $>$ EI is not statistically significant $(p=0.627)$.

Hypothesis 4 is not supported-we see that the coefficient corresponding to the path PWE $->$ PBC $\rightarrow$ EI is not statistically significant $(p=0.883)$. Thereby our data does not offer evidence in favor of a mediating effect of $\mathrm{PBC}$ on the relationship between previous working experience and EI. However, Hypothesis 5 is supported, as the coefficient of path PEE $->$ PBC $->$ EI is statistically significant $(p=002)$. Thus, we have found supporting evidence that PEE does impact the students' EI, but the relationship is mediated by PBC. 
Table 12. Results of research hypothesis H1-H5.

\begin{tabular}{|c|c|c|c|c|c|}
\hline Hypothesis & Path & Std. Beta & Std. Error & | t-value | & Decision \\
\hline \multirow{8}{*}{$\mathrm{H} 1$} & EK $->$ EA $->$ EI & $0.057^{* * *}$ & 0.022 & 2.616 & \multirow{8}{*}{ supported } \\
\hline & EK $->$ ESE $->$ EA $->$ EI & $0.042^{* * *}$ & 0.013 & 3.144 & \\
\hline & EK $->$ PBC $->$ EI & $0.040 *$ & 0.022 & 1.799 & \\
\hline & EK $->$ ESE $->$ PBC $->$ EI & $0.074^{* * *}$ & 0.018 & 4.127 & \\
\hline & IR $\rightarrow$ EA $\rightarrow$ EI & $0.097^{* * *}$ & 0.026 & 3.717 & \\
\hline & IR $->$ ESE $->$ EA $->$ EI & $0.024^{* * *}$ & 0.009 & 2.678 & \\
\hline & IR $->$ PBC $->$ EI & $0.098^{* * *}$ & 0.025 & 3.841 & \\
\hline & IR $->$ ESE $->$ PBC $->$ EI & $0.049^{* * *}$ & 0.012 & 4.085 & \\
\hline \multirow{3}{*}{$\mathrm{H} 2$} & ESE -> EA -> EI & $0.098^{* * *}$ & 0.029 & 3.308 & \multirow{3}{*}{ supported } \\
\hline & ESE -> PBC -> EI & $0.172^{* * *}$ & 0.036 & 4.873 & \\
\hline & ESE-> EI & -0.048 & 0.058 & 0.835 & \\
\hline \multirow{5}{*}{$\mathrm{H} 3$} & $\mathrm{SN}->\mathrm{EI}$ & 0.051 & 0.042 & 1.228 & \multirow{5}{*}{$\begin{array}{l}\text { partially } \\
\text { sup- } \\
\text { ported }\end{array}$} \\
\hline & $\mathrm{SN}->\mathrm{EA}->\mathrm{EI}$ & $0.095^{* * *}$ & 0.025 & 3.771 & \\
\hline & $\mathrm{SN}->\mathrm{PBC}->\mathrm{EI}$ & 0.009 & 0.018 & 0.486 & \\
\hline & $\mathrm{SN}->\mathrm{ESE}->\mathrm{PBC}->\mathrm{EI}$ & 0.074 & 0.018 & 4.085 & \\
\hline & $\mathrm{SN}->\mathrm{ESE}->\mathrm{EA}->\mathrm{EI}$ & 0.042 & 0.013 & 3.144 & \\
\hline $\mathrm{H} 4$ & PWE $->$ PBC $->$ EI & 0.003 & 0.018 & 3.041 & $\begin{array}{l}\text { not sup- } \\
\text { ported }\end{array}$ \\
\hline H5 & PEE $->$ PBC $->$ EI & 0.071 & 0.023 & $0.002^{* * *}$ & supported \\
\hline
\end{tabular}

Table 13. Results of research hypothesis H6-H7.

\begin{tabular}{|c|c|c|c|c|c|}
\hline Hypothesis & Path & $\begin{array}{l}\text { Std Beta } \\
\text { Diff } \\
\text { (M vs. W) }\end{array}$ & $\begin{array}{c}\text { t-Value } \\
\text { | M vs. W | }\end{array}$ & $\begin{array}{c}p \text {-Value } \\
\text { (M vs. W) }\end{array}$ & Decision \\
\hline \multirow{4}{*}{ H6 } & $\begin{array}{c}\text { EK -> } \\
\text { ESE }\end{array}$ & 0.352 & 3.637 & $0.000^{* * *}$ & \multirow{4}{*}{ supported } \\
\hline & $\begin{array}{c}\text { ESE -> } \\
\text { EA }\end{array}$ & 0.322 & 2.478 & $0.014 * *$ & \\
\hline & IS -> ESE & -0.246 & 2.307 & 0.022 ** & \\
\hline & IS $->$ PBC & 0.225 & 1.894 & 0.059 * & \\
\hline Hypothesis & Path & $\begin{array}{l}\text { Std Beta } \\
\text { Diff. }\end{array}$ & $\begin{array}{l}\text { t-Value } \\
\text { | U vs. R | }\end{array}$ & $\begin{array}{c}p \text {-Value } \\
\text { (U vs. R) }\end{array}$ & Decision \\
\hline \multirow{2}{*}{$\mathrm{H} 7$} & EK $->$ EA & 0.310 & 2.620 & $0.009^{* * *}$ & \multirow{2}{*}{ supportec } \\
\hline & PBC $->$ EI & 0.273 & 2.288 & $0.023^{* *}$ & \\
\hline
\end{tabular}

Results of our analysis offer support for Hypothesis 6 and 7 are presented in Table 13. By performing a multigroup analysis, we have identified the differences in the chain of relationships from the benefits of EE programs to students' EI for men versus women and, respectively, between students from rural areas and those from urban areas.

As Table 9 reveals, both men and women are capitalizing on the benefits of EK, building the practical skills necessary for entrepreneurship. However, men seem to capitalize better on the knowledge provided to them, as the estimated path coefficient for EK -> ESE is 0.646 for men compared to 0.352 for women. On the other hand, the skills necessary for entrepreneurship successfully contribute to developing women's EA, whereas our data shows that this is not the case for men. In this respect, Table 9 shows that the coefficient corresponding to the path ESE -> EA is highly statistically significant for women, whereas for men is not statistically significant. Similarly, whereas both men and women seem to capitalize on the benefits of ESE, building their PBC, results show that women are more efficient in this respect. The path coefficient corresponding to ESE -> PBC is higher for women (0.468 for women than 0.395 for men). Additionally, women seem more influenced 
by the support of their professors and team colleagues and by the inspiration provided by the EE, which they use to build positive attitudes toward entrepreneurship and practical skills necessary for entrepreneurship. In this respect, the coefficients corresponding to the paths IS -> EA and IS -> ESE are statistically significant for women but not for men.

The multigroup analysis for urban and rural environment show that, both men and women are efficient on building their ESE practical skills. However, the coefficient corresponding to the path EK -> ESE is higher for students from the urban environment $(0.489$ for the urban compared to 0.387 for the rural environment). Students from both environments are successfully transferring their practical skills related to entrepreneurship into positive attitudes towards entrepreneurship. However, those from the rural environment are more efficient in doing so, as the coefficient corresponding to path ESE -> EA is 0.278 for students from the rural environment and 0.265 for those from the urban environment. Similarly, students from the rural environment are more efficient in capitalizing on the benefits of IS for building a positive entrepreneurial attitude (the coefficient corresponding to path IS -> EA is 0.268 for students from the rural environment and 0.182 for those from the urban environment) and practical entrepreneurial skills (the coefficient corresponding to path IS -> ESE is 0.233 for students from the rural environment and 0.218 for those from the urban environment).

\section{Conclusions}

The importance-performance analysis of our study conducted among Romanian noneconomic students shows that the highest contribution to building EI is attributable to EA. Indeed, alongside public awareness raised by European and national programs for Romanian young people, the EE plays a key role in fostering positive social attitudes towards entrepreneurship. Having the greatest discrepancy between performance and importance, PBC constructs should receive the highest priority for performance improvement. Our results advocate developing the best policies to strengthen the contribution of EK, IR, and ESE's contribution to PBC. Thus, fostering a person's belief that he or she can successfully perform the various roles and tasks of entrepreneurship would directly strengthen its PBC and ultimately its EI. New teaching methods, such as case studies from the community, team-teaching, and cross-disciplinary student teams should be corroborated with informal and non-formal EE and learning by doing techniques to boost the PBC of participants in the EE program. Further on, our results advocate the importance of building IR of participants in EE programs. Thus, our study contributes to the existing literature in the field by underlining the importance of designing the best approaches for increasing the performance of PBC construct and building IR of participants in EE programs, which would ultimately positively impact the students' EI.

In our quest to better understand the transmission mechanisms involved in the relationship between EE and EI, we have underlined the broad range of approaches to model specification currently employed in the field of EI. We also have underlined the mixed results obtained, primarly related to the relationship between EE, SN, and EI. Based on these and following the recommendations in the field of Liñán and Fayolle [81] we have proposed a mediation approach to the relationship between SN and EI. As the importanceperformance matrix analysis shows, the performance of $\mathrm{SN}$ is the highest among all latent constructs considered in our analysis $(76.65 \%)$ which brings supporting evidence for our approach to specifying the relationship between $\mathrm{SN}$ and EI.

Insofar as the research methodology is concerned, we advocate the benefits of employing a partial least squares approach to the estimation of our structural model. The advantages of structural equations models have been well known. Structural equations models allow complex estimations involving latent constructs. Also, structural equations allow for estimating multiple equations and correlated errors. Structural modeling model also include the indirect effects and their statistical significance, without additional calculation required by the alternative approach suggested by Zhao et al. [16]. In addition, using the partial least squares approach to our estimation surmounted the sample size con- 
straints specific to covariance-based SEM, as shown in empirical research in the field [121]. The SMART-PLS software implementing the PLS modeling procedure has recently introduced the importance-performance matrix analysis, a valuable tool for designing helpful policy recommendations. To our knowledge, using this tool in the context of EI brings an important contribution to the existing literature in the field. Another contribution to the existing literature in the field facilitated by the PLS approach to estimation refers to its ability to switch from reflective to formative approach, which can be particularly helpful when dealing with only a small number of indicator variables.

Nevertheless, we acknowledge an ongoing debate regarding the advantages of PLS over the traditional covariance-based SEM models. In particular, Henseler [128] argues that bootstrapping procedure employed by PLS actually work well only for large samples. Moreover, evaluating the model fit in PLS models is still in infancy, despite several indices already available for evaluating the model's overall fit [128].

Our results offer valuable policy insights at the national level also. Given the specific of inclusive entrepreneurship in Romania, we have focused on identifying how the benefits of EE could be better capitalized with a positive social impact for students 'at-risk'. As the discussion in Section 6 has revealed, both multigroup analyses support similar policy recommendations. Results provide supporting evidence for the efficiency of building practical skills related to entrepreneurship as a tool for boosting the EI of students from rural areas and for women as categories 'at-risk' in the labor market. According to our results, professors, classmates, or external experts invited to a business plan competition are also likely to be efficient in helping women and rural students to build their ESE and EA. Moreover, faculty and colleagues are valuable resources, efficiently helping students from rural areas to build their EI. Obviously, these results apply to Romanian students from noneconomic specializations enrolled in our cross-campus EE program. Additional research is needed in order to extend the same policy recommendations internationally. Nevertheless, we are hoping that these results are valuable in informing national policymakers in their efforts to reforms EE in Romania.

Compared with previous studies in the field at the national level $[50,51,54]$, our cross-campus working sample with students from 14 non-economics fields of studies respond to the increasing demand for EE outside the Economics and Business schools. Economics students benefit from many other courses that influence EI. Concentrating on non-economics students, we believe that we have succeeded in better isolating the effects of EE on EI. Also, by taking advantage of the benefits of SEM, we follow the recommendation of [54], filling an existing gap in the EI estimations at the national level.

Even if our study uses a national sample, the EE program implemented at the University of Oradea, by increasing the EI of participants is also contributing to positive social benefits for categories at risk in the labor market, providing a positive example that can be emulated internationally for promoting the attractiveness of EE programs and inclusiveness of categories at risk in the labor market. Our data collected at the middle of the program suggest that we still have a long way to conclude regarding the impact of EE on non-economic students' EI. We intend to continue our analysis and further analyze to what intent the pandemic crisis has affected the EI of our students and the transmission mechanisms of the benefits of the EE program.

In the Romanian context, we consider that an interesting and unexploited perspective of research development is related to the entrepreneurial teaching methods for the students from the rural area, considering how much the urban-rural divide has aggravated in Romania in the last years. Stimulating young entrepreneurship towards non-agricultural activities in rural areas, with special attention to women, is a way out of subsistence farming dependence and poverty. Also, an extremely interesting future research direction will investigate the impact of EE on EI controlling for the students' field of study.

Considering the recommendation existing in the field, we intend to employ a longitudinal approach to our estimation of EI and compare the efficiency of dynamic panel and longitudinal SE estimations. A dynamic panel estimation is theoretically better suited 
for accommodating different assumptions embedded in the estimation of EI, whereas a longitudinal SEM analysis would facilitate working with complex latent constructs. A continuation of our study would allow us to better understand the consequences of the pandemic, including a better understanding of the contribution that universities through entrepreneurship programs can have to address the unbalances in the labor market.

Author Contributions: Conceptualization, A.-O.D.; Methodology, A.-O.D., E.-A.B., and A.C.; Software, I.-C.P.-C. and A.C.; Validation, A.C. and E.-A.B.; Formal analysis, A.-O.D., E.-A.B., and A.C.; Investigation, A.C.; Resources, A.-O.D., E.-A.B., and A.C.; Data curation, I.-C.P.-C.; Writing-original draft preparation, A.-O.D., E.-A.B., and A.C.; Writing-review and editing, A.-O.D. and I.-C.P.C.; Project administration, A.-O.D. All authors have read and agreed to the published version of the manuscript.

Funding: This research received no external funding.

Institutional Review Board Statement: Not applicable.

Informed Consent Statement: Informed consent was obtained from all subjects involved in the study.

Data Availability Statement: Not applicable.

Acknowledgments: The project "Entrepreneur for the future", Beneficiary: University of Oradea, Partner: Corporactive Consulting SRL; Total eligible value: 7,282,442.22 lei, Project duration: 2 years; Implementation period: 24.05.2019—26.06.2021; Project ID: 124167; Call: POCU / 379/6/21 / OS composite operation. 6.7, 6.9, 6.10; Component 1: 379 Student Entrepreneur ScholarshipActive measure to increase the participation of students from vulnerable categories in undergraduate study programs-Less developed regions; Priority Axis: Education and skills; Project co-financed by the European Social Fund through the Human Capital Operational Program 2014-2020. Web: https://antrev.uoradea.ro/ro/.

Conflicts of Interest: The authors declare no conflict of interest.

\section{References}

1. Schumpeter, J. Capitalism, Socialism, and Democracy; Harper \& Bros: New York, NY, USA, 1942.

2. Audretsch, D.B.; Keilbach, M.C.; Lehmann, E. Entrepreneurship and Economic Growth; Oxford University Press: Oxford, UK, 2006.

3. Moreland, N. Entrepreneurship and Higher Education. An Employability Perspective; Learning and Employability Series; The Higher Education Academy Innovation Way: York, UK, 2004; ISBN 1-905788-03-7.

4. Kato, S. Entrepreneurship as a Process of Self-Fulfillment: Well-Being, Affect, and Behavioral Strategies. Business AdministrationDissertation. Syracuse University: Syracuse, NY, USA, 2013. Available online: https://surface.syr.edu/busad_etd/97 (accessed on 24 September 2020).

5. Davey, T.; Hannon, P.; Penaluna, A. Entrepreneurship education and the role of universities in entrepreneurship. Ind. High. Educ. 2016, 30, 171-182. [CrossRef]

6. Pittaway, L.; Cope, J. Entrepreneurship Education. Int. Small Bus. J. Res. Entrep. 2007, 25, 479-510. [CrossRef]

7. Oosterbeek, H.; van Praag, M.; Ijsselstein, A. The impact of entrepreneurship education on entrepreneurship skills and motivation. Eur. Econ. Rev. 2010, 54, 442-454. [CrossRef]

8. Sirelkhatim, F.; Gangi, Y. Entrepreneurship education: A systematic literature review of curricula contents and teaching methods. Cogent Bus. Manag. 2015, 2, 1052034. [CrossRef]

9. Nabi, G.; Liñán, F.; Fayolle, A.; Krueger, N.; Walmsley, A. The Impact of Entrepreneurship Education in Higher Education: A Systematic Review and Research Agenda. Acad. Manag. Learn. Educ. 2017, 16, 277-299. [CrossRef]

10. Lackéus, M. Entrepreneurship in Education. What, Why, When, How; Entrepreneurship360. Available online: https://www. oecd.org/cfe/leed/BGP_Entrepreneurship-in-Education.pdf (accessed on 22 July 2020).

11. Key Competences for Lifelong Learning; European Commission. Directorate-General for Education, Youth, Sport and Culture; Publications Office of the European Union: Luxembourg, 2019; ISBN 978-92-76-00475-2.

12. Fiore, E.; Sansone, G.; Paolucci, E. Entrepreneurship Education in a Multidisciplinary Environment: Evidence from an Entrepreneurship Programme Held in Turin. Adm. Sci. 2019, 9, 28. [CrossRef]

13. Organization for Economic Co-Operation and Development and European Union. The Missing Entrepreneurs 2019: Policies for Inclusive Entrepreneurship. The Missing Entrepreneurs; OECD: Paris, France, 2019.

14. Merce, I.I.; Milin, I.A.; Petroman, C.; Ciolac, R.M. School Dropout-A Social Problem in Romania. Procedia Soc. Behav. Sci. 2015, $182,623-628$.

15. Gyonos, E. Early School Leaving: Reasons and Consequences. Theor. Appl. Econ. 2011, 18, 43-52. 
16. Zhao, X.; Lynch, J.G., Jr.; Chen, Q. Reconsidering Baron and Kenny: Myths and Truths about Mediation Analysis. J. Consum. Res. 2010, 37, 197-206. [CrossRef]

17. OECD. Inclusive Entrepreneurship Policies, Country Assessment Notes, Romania, 2020 (Romania IE-2020). Available online: https:/ / www.oecd.org/cfe/smes/Romania-IE-2020.pdf (accessed on 13 April 2021).

18. Ghinăraru, C. Romania, April 2014-In-Work Poverty in Romania-Causes and Possible Solutions. In Inclusive Entrepreneurship Policies, Country Assessment Notes. Romania; OECD: Paris, France, 2020.

19. Country Report Romania 2020. In European Semester: Assessment of Progress on Structural Reforms, Prevention and Correction of Macroeconomic Imbalances, and Results of In-Depth Reviews under Regulation (EU); Commission Staff Working Document; European Commission: Brussels, Belgium, 2020.

20. Organization for Economic Co-Operation and Development/The European Commission (OECD/EC). OECD/EC: Supporting Entrepreneurship and Innovation in Higher Education in Romania. Available online: https://heinnovate.eu/sites/default/files/ oecd_ec_supporting_entrepreneurship_and_innovation_in_higher_education_in_romania.pdf (accessed on 13 April 2021).

21. Leovaridis, C.; Frunzaru, V.; Cismaru, D. Entrepreneurial Education in Romanian Universities. In Proceedings of the INTED 2016 Conference, Valencia, Spain, 7-9 March 2016; Volume 1, pp. 92-102.

22. European Commission. Entrepreneurship in the EU and Beyond. In A Survey in the EU, EFTA Countries, Croatia, Turkey, the US, Japan, South Korea and China. Analytical Report; Flash Eurobarometer 283-The Gallup Organization; Directorate-General for Communication: Brussels, Belgium, 2009; Available online: http://www.emnconference.org/archives/data/file/section_ microfinance_europe/fl283_en.pdf (accessed on 24 September 2020).

23. Bosma, N.; Hill, S.; Ionescu-Sommers, A.; Kelley, D.; Guerrero, M.; Schott, T. Global Entrepreneurship Monitor 2020/2021 Global Report; GEM Global Entrepreneurship Monitor; Global Entrepreneurship Research Association, London Business School: London, UK, 2020.

24. Fayolle, A.; Gailly, B.; Lassas-Clerc, N. Assessing the impact of entrepreneurship education programmes: A new methodology. J. Eur. Ind. Train. 2006, 30, 701-720. [CrossRef]

25. Zhao, H.; Seibert, S.E.; Hills, G.E. The Mediating Role of Self-Efficacy in the Development of Entrepreneurial Intentions. J. Appl. Psychol. 2005, 90, 1265-1272. [CrossRef]

26. De Pillis, E.; Reardon, K.K. The influence of personality traits and persuasive messages on entrepreneurial intention. Career Dev. Int. 2007, 12, 382-396. [CrossRef]

27. Ozaralli, N.; Rivenburgh, N.K. Entrepreneurial intention: Antecedents to entrepreneurial behavior in the U.S.A. and Turkey. J. Glob. Entrep. Res. 2016, 6, 1. [CrossRef]

28. Thompson, E.R. Individual Entrepreneurial Intent: Construct Clarification and Development of an Internationally Reliable Metric. Entrep. Theory Pract. 2009, 33, 669-694. [CrossRef]

29. Iakovleva, T.; Kolvereid, L. An integrated model of entrepreneurial intentions. Int. J. Bus. Glob. 2009, 3, 66. [CrossRef]

30. Souitaris, V.; Zerbinati, S.; Al-Laham, A. Do entrepreneurship programmes raise entrepreneurial intention of science and engineering students? The effect of learning, inspiration and resources. J. Bus. Ventur. 2007, 22, 566-591. [CrossRef]

31. Shapero, A.; Sokol, L. The Social Dimension of Entrepreneurship. In Encyclopedia of Entrepreneurship; Kent, C.A., Sexton, D.L., Vesper, K.H., Eds.; Prentice Hall: Englewood Cliffs, NJ, USA, 1982; pp. 72-90.

32. Ajzen, I. The theory of planned behavior. Organ. Behav. Hum. Decis. Process. 1991, 50, 179-211. [CrossRef]

33. Krueger, N.F., Jr.; Reilly, M.D.; Carsrud, A.L. Competing models of entrepreneurial intentions. J. Bus. Ventur. 2000, 15, 411-432. [CrossRef]

34. Bandura, A. Social Foundations of Thought and Action: A Social Cognitive Theory; Prentice-Hall: Englewood Cliffs, NJ, USA, 1986.

35. Bandura, A. Self-Efficacy: The Exercise of Control; Freeman: New York, NY, USA, 1997.

36. Ajzen, I. The theory of planned behaviour: Reactions and reflections. Psychol. Health 2011, 26, 1113-1127. [CrossRef]

37. Krueger, J.N.F.; Brazeal, D.V. Entrepreneurial Potential and Potential Entrepreneurs. Entrep. Theory Pract. 1994, 18, 91-104. [CrossRef]

38. Boyd, N.G.; Vozikis, G.S. The Influence of Self-Efficacy on the Development of Entrepreneurial Intentions and Actions. Entrep. Theory Pract. 1994, 18, 63-77. [CrossRef]

39. Chen, C.C.; Greene, P.G.; Crick, A. Does entrepreneurial self-efficacy distinguish entrepreneurs from managers? J. Bus. Ventur. 1998, 13, 295-316. [CrossRef]

40. Newman, A.; Obschonka, M.; Schwarz, S.; Cohen, M.; Nielsen, I. Entrepreneurial self-efficacy: A systematic review of the literature on its theoretical foundations, measurement, antecedents, and outcomes, and an agenda for future research. J. Vocat. Behav. 2019, 110, 403-419. [CrossRef]

41. Bates, T. Entrepreneur Human Capital Inputs and Small Business Longevity. Rev. Econ. Stat. 1990, 72, 551. [CrossRef]

42. Unger, J.M.; Rauch, A.; Frese, M.; Rosenbusch, N. Human capital and entrepreneurial success: A meta-analytical review. J. Bus. Ventur. 2011, 26, 341-358. [CrossRef]

43. Crook, T.R.; Todd, S.Y.; Combs, J.G.; Woehr, D.J.; Ketchen, D.J. Does human capital matter? A meta-analysis of the relationship between human capital and firm performance. J. Appl. Psychol. 2011, 96, 443-456. [CrossRef] [PubMed]

44. Bosma, N.; Stam, E.; Wennekers, S. Intrapreneurship -An International Study; EIM Research Reports; EIM: Zoetermeer, The Netherlands, 2010. 
45. Rauch, A.; Frese, M. Psychological approaches to entrepreneurial success: A general model and an overview of findings. In International Review of Industrial and Organizational Psychology; Wiley: Chichester, UK, 2000; pp. 101-142.

46. Krabel, S. Are entrepreneurs made on campus? The impact of entrepreneurial universities and graduates' human capital on graduates' occupational choice. J. Int. Entrep. 2017, 16, 456-485. [CrossRef]

47. Oftedal, E.M.; Iakovleva, T.A.; Foss, L. University context matter. Educ. Train. 2018, 60, 873-890. [CrossRef]

48. Kolvereid, L. Prediction of Employment Status Choice Intentions. Entrep. Theory Pract. 1996, 21, 47-58. [CrossRef]

49. Mazzarol, T.; Volery, T.; Doss, N.; Thein, V. Factors influencing small business start-ups. Int. J. Entrep. Behav. Res. 1999, 5, 48-63. [CrossRef]

50. Alexe, C.G.; Deselnicu, D.C.; Ioanid, A.; Tigănoaia, B.; Mustață, C. Entrepreneurship Education between Perceptions and Expectations. Case Study; University Politehnica of Bucharest: Valencia, Spain, 2018; pp. 791-799.

51. Szabo, Z.; Marian, L. Pedagogical Methods and Models for Entrepreneurship Education in Romania: Case Study. In Proceedings of the 6th European Conference on Innovation and Entrepreneurship, ECIE 2011; Academic Conferences and Publishing International Limited: Aberdeen, Scotland, UK, 15 September 2011; pp. 805-811.

52. Fellnhofer, K.; Puumalainen, K. Can role models boost entrepreneurial attitudes? Int. J. Entrep. Innov. Manag. 2017, 21, 274-290. [CrossRef] [PubMed]

53. Soria-Barreto, K.; Honores-Marin, G.; Gutiérrez-Zepeda, P.; Gutiérrez-Rodríguez, J. Prior Exposure and Educational Environment towards Entrepreneurial Intention. J. Technol. Manag. Innov. 2017, 12, 45-58. [CrossRef]

54. Vodă, A.I.; Florea, N. Impact of Personality Traits and Entrepreneurship Education on Entrepreneurial Intentions of Business and Engineering Students. Sustainability 2019, 11, 1192. [CrossRef]

55. Morillo, B.J.; Avila-Rondon, M.; Alfaro-Pozo, R. Analysis of Knowledge, Perception and Assessment of Innovation and Entrepreneurship Competence by Bachelor's Degree Students. In Proceedings of the Rethinking Learning in a Connected Age, Valencia, Spain, 5 March 2018; pp. 3157-3160.

56. Overall, J.; Gedeon, S.A.; Valliere, D. What can universities do to promote entrepreneurial intent? An empirical investigation. Int. J. Entrep. Ventur. 2018, 10, 312. [CrossRef]

57. Turner, T.; Gianiodis, P. Entrepreneurship Unleashed: Understanding Entrepreneurial Education outside of the Business School. J. Small Bus. Manag. 2018, 56, 131-149. [CrossRef]

58. Barba-Sánchez, V.; Atienza-Sahuquillo, C. Entrepreneurial intention among engineering students: The role of entrepreneurship education. Eur. Res. Manag. Bus. Econ. 2018, 24, 53-61. [CrossRef]

59. Schneider, M. Kauffman Campuses Initiative: A Study That Explores the Phenomenon of Cross-Campus Entrepreneurship. Ph.D. Thesis, University of Pennsylvania, Philadelphia, PA, USA, 2015.

60. Katz, J.A.; Roberts, J.; Strom, R.; Freilich, A. Perspectives on the Development of Cross Campus Entrepreneurship Education. Entrep. Res. J. 2013, 4, 4. [CrossRef]

61. Welsh, D.H.B. Creative Cross-Disciplinary Entrepreneurship: A Practical Guide to a Cross Campus Program; Palgrave-MacMillan: New York, NY, USA, 2014.

62. Morris, N.M.; Kuratko, D.F.; Pryor, C.G. Building Blocks for the Development of University-Wide Entrepreneurship. Entrep. Res. J. 2013, 4, 45-68. [CrossRef]

63. Streeter, D.H.; Jaquette, J.P.; Hovis, K.; Streeter, D.H.; Jaquette, J.P.; Hovis, K. University-Wide Entrepreneurship Education: Alternative Models and Current Trends; Cornell University: Ithaka, NY, USA, 2002. [CrossRef]

64. Roberts, J.; Hoy, F.; Katz, J.A.; Neck, H. The Challenges of Infusing Entrepreneurship within Non-Business Disciplines and Measuring Outcomes. Entrep. Res. J. 2014, 4, 1-12. [CrossRef]

65. Roberts, J. Infusing Entrepreneurship Within Non-Business Disciplines: Preparing Artists and Others for Self-Employment and Entrepreneurship. J. Entrep. Arts 2012, 1, 53-63.

66. Decker-Lange, C. Three Reasons Why We Should Think about Employability in Entrepreneurship Education; Centre for Innovation in Legal and Business Education (SCiLAB), Faculty of Business and Law, The Open University: Milton Keynes, UK, 2021.

67. Pilková, A.; Jančovičová, Z.; Kovačičová, Z. Inclusive Entrepreneurship in Visegrad4 Countries. Procedia Soc. Behav. Sci. 2016, 220, 312-320. [CrossRef]

68. Organisation for Economic Co-Operation and Development/The European Commission (OECD/EC) (Ed.) The Missing Entrepreneurs: Policies for Inclusive Entrepreneurship in Europe; OECD Publishing: Paris, France, 2013; pp. 18-19.

69. Dodescu, A.O.; Cohut, I.C.P. Youth Entrepreneurship and Role Models at Local Level. Case Study: Bihor County, Romania. In Proceedings of the Rethinking Social Action. Core Values in Practice; LUMEN Publishing: Iasi, Romania, 2018; pp. 117-134.

70. Dodescu, A.; Pop-Cohuţ, I. Inclusive Entrepreneurship in Romania in the Context of European Union: Theoretical Issues and Emerging Challenges. In Proceedings of the 6th LUMEN International Conference on Rethinking Social Action Core Values, Iasi, Romania, 16-19 April 2015; pp. 463-468. Available online: https://moam.info/rethinking-social-action-core-values_5977936b1 723dde28b57d429.html (accessed on 24 May 2021).

71. Dodescu, A.; Cohuţ, I.P.; Borma, A. A local perspective about students' entrepreneurship. Evidence from Romania. Integr. Politics Res. Innov. 2018, 393-403. [CrossRef]

72. Lazăr, A.; Hatos, A. European Philanthropic Behavior Patterns: Charitable Giving, Non-Profit and Welfare Regimes in the European Union. Transylv. Rev. Adm. Sci. 2019, 15, 21-40. [CrossRef] 
73. Reynolds, P.D.; Hay, M.; Bygrave, W.D.; Camp, S.M.; Autio, E. Global Entrepreneurship Monitor: 2000 Executive Report; Kauffman Center for Entrepreneurial Leadership at the Ewing Kaufman Foundation: Kansas, MO, USA, 2001. [CrossRef]

74. Aldrich, J. Fisher and Regression. Stat. Sci. 2005, 20, 401-417. [CrossRef]

75. Yang, T.; Aldrich, H.E. Who's the Boss? Explaining Gender Inequality in Entrepreneurial Teams. Am. Sociol. Rev. 2014, 79, 303-327. [CrossRef]

76. Ahl, H. Why Research on Women Entrepreneurs Needs New Directions. Entrep. Theory Pract. 2006, 30, 595-621. [CrossRef]

77. Lewis, H.R. Excellence without a Soul: Does Liberal Education Have a Future? PublicAffairs: New York, NY, USA, 2007; ISBN 978-1-58648-501-6.

78. Gupta, V.K.; Turban, D.B.; Wasti, S.A.; Sikdar, A. The Role of Gender Stereotypes in Perceptions of Entrepreneurs and Intentions to Become an Entrepreneur. Entrep. Theory Pract. 2009, 33, 397-417. [CrossRef]

79. Fini, R.; Grimaldi, R.; Marzocchi, G.L.; Sobrero, M. The Foundation of Entrepreneurial Intention. In Proceedings of the Summer Conference 2009, Istanbul, Turkey, 13-16 June 2009; pp. 17-19.

80. Lortie, J.; Castogiovanni, G. The theory of planned behavior in entrepreneurship research: What we know and future directions Int. Entrep. Manag. J. 2015, 11, 935-957. [CrossRef]

81. Liñán, F.; Fayolle, A. A systematic literature review on entrepreneurial intentions: Citation, thematic analyses, and research agenda. Int. Entrep. Manag. J. 2015, 11, 907-933. [CrossRef]

82. Dodescu, A.O.; Botezat, E.A.; Cohut, I.C.P.; Borma, A. Antecedents, Experiences and Entrepreneurial Intentions among Economics Students. In Proceedings of the 12th LUMEN International Scientific Conference Rethinking Social Action, Core Values in Practice RSACVP 2019, Iasi, Romania, 15-17 May 2019; LUMEN Publishing: Iasi, Romania, 2019; pp. 89-107.

83. Pruett, M.; Shinnar, R.S.; Toney, B.; Llopis, F.; Fox, J. Explaining entrepreneurial intentions of university students: A cross-cultural study. Int. J. Entrep. Behav. Res. 2009, 15, 571-594. [CrossRef]

84. Franke, N.; Lüthje, C. Entrepreneurial intentions of business students-A benchmarking study. Int. J. Innov. Technol. Manag. 2004, 1, 269-288. [CrossRef]

85. Fayolle, A.; Gailly, B. From craft to science. J. Eur. Ind. Train. 2008, 32, 569-593. [CrossRef]

86. Fretschner, M.; Weber, S. Measuring and Understanding the Effects of Entrepreneurial Awareness Education. J. Small Bus. Manag. 2013, 51, 410-428. [CrossRef]

87. Liñan, F.M.; Rodríguez-Cohard, J.C.; Rueda-Cantuche, J.M. Factors affecting entrepreneurial intention levels: A role for education. Int. Entrep. Manag. J. 2011, 7, 195-218. [CrossRef]

88. von Graevenitz, G.; Harhoff, D.; Weber, R. The effects of entrepreneurship education. J. Econ. Behav. Organ. 2010, 76, 90-112. [CrossRef]

89. Peterman, N.E.; Kennedy, J. Enterprise Education: Influencing Students' Perceptions of Entrepreneurship. Entrep. Theory Pract. 2003, 28, 129-144. [CrossRef]

90. Wilson, F.; Kickul, J.; Marlino, D. Gender, Entrepreneurial Self-Efficacy, and Entrepreneurial Career Intentions: Implications for Entrepreneurship Education. Entrep. Theory Pract. 2007, 31, 387-406. [CrossRef]

91. Sanchez, G. PLS Path Modeling with R; Trowchez Editions: Berkeley, CA, USA, 2013.

92. Radipere, S. South African university entrepreneurship education. Afr. J. Bus. Manag. 2012, 6, 11015-11022. [CrossRef]

93. Solomon, G.T.; Duffy, S.; Tarabishy, A. The State of Entrepreneurship Education in The United States: A Nationwide Survey and Analysis. Int. J. Entrep. Educ. 2002, 1, 1-22.

94. Laukkanen, M. Exploring academic entrepreneurship: Drivers and tensions of university-based business. J. Small Bus. Enterp. Dev. 2003, 10, 372-382. [CrossRef]

95. Clark, B.W.; Davis, C.H.; Harnish, V.C. Do Courses in Entrepreneurship Aid in New Venture Creation? J. Small Bus. Manag. 1984, 2, 26-31.

96. Liñán, F. Intention-Based Models of Entrepreneurship Education. Piccolla Impresa/Small Bus. 2004, 3, 11-35.

97. Shahab, Y.; Chengang, Y.; Arbizu, A.D.; Haider, M.J. Entrepreneurial self-efficacy and intention: Do entrepreneurial creativity and education matter? Int. J. Entrep. Behav. Res. 2019, 25, 259-280. [CrossRef]

98. Peng, M.W. New Research Directions in the Institution-Based View. In Research in Global Strategic Management; Boddewyn, J.J., Ed.; Emerald Group Publishing Limited: Bingley, UK, 2014; Volume 16, pp. 59-78. ISBN 978-1-78441-039-1.

99. Amofah, K.; Saladrigues, R.; Akwaa-Sekyi, E.K. Entrepreneurial intentions among MBA students. Cogent Bus. Manag. 2020, 7, 1832401. [CrossRef]

100. Liñán, F.; Chen, Y.-W. Development and Cross-Cultural Application of a Specific Instrument to Measure Entrepreneurial Intentions. Entrep. Theory Pract. 2009, 33, 593-617. [CrossRef]

101. Veciana, J.M.; Aponte, M.; Urbano, D. University Students' Attitudes Towards Entrepreneurship: A Two Countries Comparison. Int. Entrep. Manag. J. 2005, 1, 165-182. [CrossRef]

102. Autio, E.; Keeley, R.H.; Klofsten, M.; Parker, G.G.C.; Hay, M. Entrepreneurial Intent among Students in Scandinavia and in the USA. Enterp. Innov. Manag. Stud. 2001, 2, 145-160. [CrossRef]

103. Kolvereid, L.; Isaksen, E. New business start-up and subsequent entry into self-employment. J. Bus. Ventur. 2006, 21, 866-885. [CrossRef]

104. Tkachev, A.; Kolvereid, L. Self-employment intentions among Russian students. Entrep. Reg. Dev. 1999, 11, 269-280. [CrossRef] 
105. Tsai, K.-H.; Chang, H.-C.; Peng, C.-Y. Extending the link between entrepreneurial self-efficacy and intention: A moderated mediation model. Int. Entrep. Manag. J. 2016, 12, 445-463. [CrossRef]

106. Krueger, N. The Impact of Prior Entrepreneurial Exposure on Perceptions of New Venture Feasibility and Desirability. Entrep. Theory Pract. 1993, 18, 5-21. [CrossRef]

107. Miralles, F.; Giones, F.; Riverola, C. Evaluating the impact of prior experience in entrepreneurial intention. Int. Entrep. Manag. J. 2016, 12, 791-813. [CrossRef]

108. Yuan, L.W.; Ali Qalati, S.A.; Iqbal, S.; Hussain, R.Y.; Ali, S. Impact of Prior Work Experience on Entrepreneurial Intention and Theory of Planned Behaviour in the Context of Pakistan. J. Entrep. Organ. Manag. 2019, 8, 268.

109. Fatoki, O. The Entrepreneurial Intention of Undergraduate Students in South Africa: The Influences of Entrepreneurship Education and Previous Work Experience. Mediterr. J. Soc. Sci. 2014, 5, 294. [CrossRef]

110. Lorz, M. The Impact of Entrepreneurship Education on Entrepreneurial Intention. Ph.D. Thesis, School of Management, Economics, Law, Social Sciences and International Affairs, University of St. Gallen, St. Gallen, Switzerland, 2011.

111. Barakat, S.; Boddington, M.; Vyakarnam, S. Measuring entrepreneurial self-efficacy to understand the impact of creative activities for learning innovation. Int. J. Manag. Educ. 2014, 12, 456-468. [CrossRef]

112. Ndofirepi, T.M. Relationship between entrepreneurship education and entrepreneurial goal intentions: Psychological traits as mediators. J. Innov. Entrep. 2020, 9, 1-20. [CrossRef]

113. Botezat, E.A.; Dodescu, A.O.; Vaduva, S.; Fotea, S.L. An Exploration of Circular Economy Practices and Performance Among Romanian Producers. Sustainability 2018, 10, 3191. [CrossRef]

114. Netemeyer, R.G.; Bearden, W.O.; Sharma, S. Scaling Procedures: Issues and Applications; Sage: Thousand Oaks, CA, USA, 2003.

115. Rossiter, J.R. The Five Forms of Transmissible, Usable marketing Knowledge. Mark. Theory 2002, 2, 369-380. [CrossRef]

116. Jarvis, C.B.; MacKenzie, S.B.; Podsakoff, P.M. A Critical Review of Construct Indicators and Measurement Model Misspecification in Marketing and Consumer Research. J. Consum. Res. 2003, 30, 199-218. [CrossRef]

117. Albu, M. Construirea şi Utilizarea Testelor Psihologice; Cluj-Napoca: Clusium, Italy, 1998.

118. Dunn, S.; Seaker, R.; Waller, M. Latent Variables in Business Logistics Research: Scale Development and Validation. J. Bus. Logist. 1994, 14, 145.

119. Sarstedt, M.; Ringle, C.M.; Hair, J.F. Partial Least Squares Structural Equation Modeling. In Handbook of Market Research; Homburg, C., Klarmann, M., Vomberg, A., Eds.; Springer: Cham, Switzerland, 2017; pp. 1-40. ISBN 978-3-319-05542-8.

120. Chin, W.W.; Newsted, P.R. Structural equation modeling analysis with small samples using partial least squares. In Statistical Strategies for Small Sample Research; Hoyle, R.H., Ed.; Sage Publications: Thousand Oaks, CA, USA, 1999; pp. $307-341$.

121. Hair, J.F.; Hult, G.T.M.; Ringle, C.M.; Sarstedt, M. Primer on Partial Least Squares Structural Equation Modeling (PLS-SEM), 2nd ed.; Sage Publications Inc.: Thousand Oaks, CA, USA, 2017.

122. Hulland, J. Use of Partial Least Squares (PLS) in Strategic Management Research: A Review of Four Recent Studies. Strat. Mgmt. J. 1999, 20, 195-204. [CrossRef]

123. Nunnally, J.C. Psychometric Theory, 2nd ed.; McGraw-Hill: New York, NY, USA, 1994; ISBN 007047849X.

124. Gefen, D.; Straub, D.; Boudreau, M. Structural equation modeling and regression: Guidelines for research practice. Commun. Assoc. Inf. Syst. 2000, 4, 407. [CrossRef]

125. Bagozzi, R.P.; Yi, Y. On the evaluation of structural equation models. J. Acad. Mark. Sci. 1988, 16, 74-94. [CrossRef]

126. Chin, W.W. The partial least squares approach for structural equation modeling. In Modern Methods for Business Research; Methodology for Business and Management; Lawrence Erlbaum Associates Publishers: Mahwah, NJ, USA, 1998 ; pp. $295-336$. ISBN 0-8058-2677-7.

127. Hu, L.-T.; Bentler, P.M. Fit indices in covariance structure modeling: Sensitivity to underparameterized model misspecification. Psychol. Methods 1998, 3, 424-453. [CrossRef]

128. Henseler, J.; Dijkstra, T.K.; Sarstedt, M.; Ringle, C.M.; Diamantopoulos, A.; Straub, D.W.; Ketchen, J.D.J.; Hair, J.F.; Hult, G.T.M.; Calantone, R.J. Common Beliefs and Reality About PLS. Organ. Res. Methods 2014, 17, 182-209. [CrossRef] 